NBER WORKING PAPER SERIES

\title{
MINORITY SELF-EMPLOYMENT IN THE UNITED STATES AND THE IMPACT OF AFFIRMATIVE ACTION PROGRAMS
}

\author{
David G. Blanchflower \\ Working Paper 13972 \\ http://www.nber.org/papers/w13972 \\ NATIONAL BUREAU OF ECONOMIC RESEARCH \\ 1050 Massachusetts Avenue \\ Cambridge, MA 02138
}

May 2008

I thank Cary Donham, Jack Hagerty and John T. Scott for helpful comments and suggestions. I also thank an anonymous referee and the editors of the symposium, Anne Villamil and Cristina De Nardi for their helpful comments and suggestions. All errors are mine. The views expressed herein are those of the author(s) and do not necessarily reflect the views of the National Bureau of Economic Research.

NBER working papers are circulated for discussion and comment purposes. They have not been peerreviewed or been subject to the review by the NBER Board of Directors that accompanies official NBER publications.

(C) 2008 by David G. Blanchflower. All rights reserved. Short sections of text, not to exceed two paragraphs, may be quoted without explicit permission provided that full credit, including $\odot$ notice, is given to the source. 
Minority Self-Employment in the United States and the Impact of Affirmative Action Programs David G. Blanchflower

NBER Working Paper No. 13972

April 2008

JEL No. J71

\begin{abstract}
$\underline{\text { ABSTRACT }}$
In this paper I examine changes in self-employment that have occurred since the early 1980s in the United States. It is a companion paper to a recent equivalent paper that related to the UK. Data on random samples of approximately twenty million US workers are examined taken from the Basic Monthly files of the CPS (BMCPS), the 2000 Census and the 2006 American Community Survey (ACS). In contrast to the official definition of self-employment which simply counts the numbers of unincorporated self-employed, we also include the incorporated self-employed who are paid wages and salaries. The paper presents evidence on trends in self-employment for the US by race, ethnicity and gender. Evidence is also presented for construction which has self-employment rates roughly double the national rates and where there are strikingly high racial and gender disparities in self-employment rates. The construction sector is also important given the existence of public sector affirmative action programs at the federal, state and local levels directed at firms owned by women and minorities. I document the fact that disparities between the self-employment rates of white men and white women and minorities in construction narrowed in the 1980s, widened during the 1990s after the US Supreme Court's decision in Croson but then narrowed again since 2000 after a number of legal cases, which found such programs constitutional. Despite this substantial disparities remain, particularly in earnings. I also find evidence of discrimination in the small business credit market. Firms owned by minorities in general and blacks in particular are much more likely to have their loans denied and pay higher interest than is the case for white males. This is only partially explained by their lack of creditworthiness and is consistent with a finding of discrimination in the credit market by banks.
\end{abstract}

David G. Blanchflower

Bruce V. Rauner Professor of Economics

309B Silsby Hall

Dartmouth College

Hanover, NH 03755-3514

and NBER

david.g.blanchflower@dartmouth.edu 
In a recent paper I examined the causes and consequences of changes in the incidence of entrepreneurship in the UK (Blanchflower and Shadforth, 2007). In that paper entrepreneurship was restricted to the self-reported self-employed. Of particular interest in that paper was the fact that over the period 2004-2006 two-thirds of all the job growth in the UK was in selfemployment. Also relevant in the UK was the impact of a large influx of workers since May 2004 when the eight countries from Eastern Europe joined the EU and had the right to work in the UK. This is the sister paper focusing on the main issues of self-employment in the United States where the main issues relate to race and gender and the importance of capital constraints. In both countries the construction industry is a major source of self-employed jobs and is a particular focus of this paper, given the existence in the United States of affirmative action programs designed to help women and minorities alongside other legislation specific to construction such as Prevailing Wage Laws at both the state and federal level.

In this paper I now examine changes in self-employment that has occurred since the early 1980s in the United States, using data at both the individual and the (small) firm level. As was done in the UK paper I will also base my definition of entrepreneurship around the concept of selfemployment with the unit of observation primarily the individual based on self-reports, but also on the small firm and any difficulties it faces in the credit market. Data on random samples of twenty million individuals are examined taken from the Basic Monthly files of the CPS (BMCPS), the 2000 census and the 2006 American Community Survey (ACS). In contrast to the official definition of self-employment which simply counts the numbers of unincorporated selfemployed, I also include the incorporated self-employed who are paid wages and salaries. This definition of self-employment is more comparable to that used internationally (Blanchflower, 2000, 2004 and Blanchflower and Shadforth, 2007). In the first section of the paper I examine the literature on self-employment and discuss race, ethnic and gender differences. I examine the construction industry and report on the various affirmative action programs that have been implemented in that sector to overcome the evidence of pervasive discrimination in the sector. The section also examines evidence on the importance of capital constraints using data on firms. Section two provides empirical evidence on the incidence of self-employment by race, ethnicity and gender and how it has changed over time in the US as a whole and in construction in particular. The third section examines data on small firms on the extent to which capital constraints bind on firms owned by minorities and women. The data at the level of the firm are taken from the 2003 Survey of Small Business Finances conducted by the Reserve Board of Governors. Minority-owned firms in general and African-American owned firms in particular have higher denial rates when they apply for loans and pay higher interest rates when they do obtain loans. I find no evidence of differences in the availability of credit cards, where race is not know by the bank, which suggests that these differences are not due to unobservables such as creditworthiness but rather to discrimination. The final section presents my conclusions.

\section{Previous evidence on self-employment in the United States}

A strong decline in agricultural self-employment has been observed in the US and elsewhere over the last fifty years or so (Blanchflower, 2000). To put the US evidence in context, Table 1 shows that self-employment rates, in the non-agricultural sector in the US have remained virtually unchanged since the 1970s. This is not typical across the OECD where quite different trends in non-agricultural self-employment rates have been observed. According to the 2004 OECD Labour Force Statistics which provides comparable non-agricultural self-employment 
rates by country, there are very diverse paths in self-employment rates by country. For example, there is a downward trend from the 1970s in eight countries (Austria, Denmark, France, Greece, Japan, Luxembourg, Norway and Spain) but an upward trend in fourteen (Australia, Canada, Finland, Germany, Iceland, Ireland, Italy, Mexico, Netherlands, New Zealand, Poland, Portugal, Sweden, and the United Kingdom). It is perhaps unsurprising then that little evidence can be found between changes in self-employment and macro indicators such as changes in GDP per capita by country (Blanchflower and Shadforth, 2007). Also of note is that rates of nonagricultural self-employment in the US are low by international standards. In Table 1 for 2005 the US ranked $26^{\text {th }}$ out of 28 countries.

As the time trend in self-employment in the US has essentially been flat over time, the main issues in research in the US on self-employment and entrepreneurship do not relate to the time series movements in self-employment but rather to racial and gender differences in selfemployment. We also explicitly look in some detail at the construction sector which is the industry with a particularly high proportion of workers who are self-employed and where minorities and women are significantly under-represented. Construction is also the sector where affirmative action programs have most commonly been implemented by federal, state and local governments in order to help to overcome discrimination in the marketplace against women and minority-owned business enterprises (MWBEs). Finally, we look at the importance of capital constraints in limiting the supply of MWBEs. I now turn to examine each of these factors in further detail.

\subsection{Racial and gender differences in self-employment}

A major research question for scholars has been to understand why the self-employment rate of minorities in general and blacks in particular is so low. For example in 2003, using data on nonagricultural self-employment from the Outgoing Rotation Group files of the Current Population Survey, defined to include both incorporated and unincorporated, Robert Fairlie reports the following self-employment rates. ${ }^{1}$

$\begin{array}{lr}\text { All } & 9.8 \% \\ \text { Males } & 12.8 \% \\ \text { Females } & 6.8 \% \\ \text { Whites (non-Latino) } & 11.1 \% \\ \text { White males } & 14.1 \% \\ \text { White female } & 7.5 \% \\ \text { Black } & 5.2 \% \\ \text { Black males } & 7.2 \% \\ \text { Black females } & 3.4 \% \\ \text { Asians } & 10.4 \% \\ \text { Asian males } & 11.5 \% \\ \text { Asian females } & 9.2 \% \\ \text { Hispanics } & 7.0 \% \\ \text { Hispanic males } & 8.1 \% \\ \text { Hispanic females } & 5.3 \%\end{array}$

${ }^{1}$ http://people.ucsc.edu/ fairlie/serates/sesex7903data.xls 
Approximately one in ten workers in the US are self-employed; one in seven white males are self-employed. Interestingly Asian women have higher self-employment rates than white women (9.1\% and $7.6 \%$ respectively). ${ }^{2}$ Particularly striking though is the very low self-employment rates for both black men and black women and to a lesser extent Hispanics. A continuing puzzle in the literature in the U.S. has been to determine why this is so. Fairlie and Meyer (2000), rule out a number of explanations for the difference in the self-employment rates of white and black males. They found that trends in demographic factors, including the Great Migration and the racial convergence in education levels "did not have large effects on the trend in the racial gap in self-employment" (p. 662). They also found that an initial lack of business experience "cannot explain the current low levels of black self-employment." Further, they found that "the lack of traditions in business enterprise among blacks that resulted from slavery cannot explain a substantial part of the current racial gap in self-employment” (p. 664). Fairlie (1999) and Wainwright (2000) have shown that a considerable part of the explanation of the differences between the African American and white self-employment rate can be attributed to discrimination. Bates (1989) finds strong supporting evidence that racial differences in levels of financial capital have significant effects upon racial patterns in business failure rates. Fairlie (1999) also found that the black exit rate from self-employment is twice as high as that of whites.

Another important determinant of being self-employed that has been identified in the literature is having a self-employed parent. The probability of self-employment is substantially higher among the children of business owners than among the children of non-business owners (see Dunn and Holtz-Eakin 2000, and Hout and Rosen, 2000). These studies generally find that an individual who had a self-employed parent is roughly two to three times more likely to be self-employed than someone who did not have a self-employed parent. More recently Fairlie and Robb (2007a) have demonstrated using data from the 1992 Characteristics of Business Owners (CBO) Survey found that more than half of all business owners had a self-employed family member prior to starting their business. Conditional on having a self-employed family member, less than 50 percent of small business owners worked in that family member's business suggesting that it is unlikely that intergenerational links in self-employment are largely due to the acquisition of general and specific business human capital and that instead similarities across family members in entrepreneurial preferences may explain part of the relationship. In contrast, estimates from regression models conditioning on business ownership indicated that having a self-employed family member plays only a minor role in determining small business outcomes, whereas the business human capital acquired from prior work experience in a family member's business appears to be very important for business success. Estimates from the CBO also indicated that only 1.6 percent of all small businesses are inherited suggesting that the role of business inheritances in determining intergenerational links in self-employment is limited at best.

Using the same 1992 Characteristics of Business Owners (CBO) Survey, Fairlie and Robb (2007b) examined why African-American owned businesses lag substantially behind whiteowned businesses in sales, profits, employment, and survival. Black business owners, they found, were much less likely than white owners to have had a self-employed family member owner prior to starting their business and are less likely to have worked in that family member's

\footnotetext{
2 The CPS does not allow identification of Asians and Native Americans prior to 1989.
} 
business. They found further that the lack of prior work experience in a family business among black business owners, perhaps by limiting their acquisition of general and specific business human capital, negatively affects black business outcomes

The gap between the black and white male self-employment rates has persisted for the best part of a century. As Fairlie and Meyer (2000) note:

"The constancy of the black/white ratio is surprising in light of the substantial gains blacks have made in education, earnings and civil rights during the twentieth century... and the numerous government programs created to promote minority business ownership” (p. 656)

In contrast, there has been a striking growth over time in the self-employment rate of females. Devine (1994) showed, using the March Current Population Survey data that the number of selfemployed females aged 18-64 in the non-agricultural sector increased by 2.2 million or 145 percent between 1975 and 1990. This represented an increase in the self-employment rate from 4 percent to 6.6 percent. There has also been substantial growth of self-employment among Hispanics. The number of Hispanic owned businesses has grown substantially over the past couple of decades. Fairlie (2004) showed that there were 435,000 more Hispanic business owners in 1998 than in 1979, representing a growth rate of 193 percent. The most recent results from the Hispanic-Owned Firms: 2002 (U.S. Department of Commerce 2006) show that 1.57 million Hispanic-owned businesses operate in the United States. The significant growth rate of 31 percent (three times the rate of the national average, 10 percent) between 1997 and 2002 among Latino establishments has outpaced all other U.S. populations. Fairlie (2004) also noted that the growth in the number of Hispanic self-employed over the period using the Outgoing Rotation Group files of the Current Population Survey from the beginning of the 1980s to the end of the 1990s was especially pronounced both overall and in construction. The growth rates, in construction reported by Fairlie (2004, Table 1) over this period were 34\% for whites; $72 \%$ for blacks and $154 \%$ for Hispanics. ${ }^{3}$

\subsection{The Construction Industry}

In 2006, approximately 11.75 million workers, or approximately 8.1 per cent of total employment in the United States, held a construction job of whom 9.6\% (46.3 \%) were female; $5.5 \%$ (10.9\%) were black or African-American and 25.1\% (13.6\%) were Latino or Hispanic with US aggregates for all workers in parentheses. ${ }^{4}$ The representation of minorities in particular among the ownership of firms in construction is well below their representation in the population as a whole. According to the 2002 Economic Census Survey of Business Owners, of the 2,770,888 firms in construction, 2.4\% were owned by African Americans; $7.0 \%$ by Hispanics;

${ }^{3}$ For a discussions of Hispanic self-employment and entrepreneurship see Robles and Cordero-Guzmán (2007); Olson et al (2000); Mora and Da'vila (2006) and Zuiker et al (2003). In a recent review Robles and CorderoGuzmán (2007) suggest that educational attainment rates, individual or family personal wealth, customer demographics, age of enterprise, age of owner, and particularly access to financial capital are significant variables in explaining Latino self-employment rates and business ownership success and failure.

${ }^{4}$ Source: Table 602 Statistical Abstract of the United States 2008 downloadable at http://www.census.gov/compendia/statab/cats/labor_force_employment_earnings.html 
1.1\% by American Indians or Alaskan natives; 1.4\% by Asians and Pacific Islanders and 10.5\% by women. As a proportion of the population, according to the 2008 Statistical Abstract of the United States Table 13, in 2006 African Americans were 12.8\%; white Hispanics 13.7\%; Asian/Pacific Islanders 4.6\%; American Indians/Alaskan Native $1.0 \%$ and two or more races $1.8 \%$.

Ray Marshall (2000) has noted that there are several factors that make the construction industry especially important for minority development because it "provides opportunity for upward occupational mobility since workers commonly become managers and contractors". Glover (1977) notes that minorities have a long tradition in this industry as laborers, skilled workers and contractors and that it is possible to increase minority employment and income more effectively in construction than is the case with most other minority businesses.

There is a good deal of evidence to suggest that the under-representation of women and minorities in construction especially is due to widespread and pervasive discrimination that has changed little over time. Not only is the proportion of firms owned by African Americans especially relatively low, so also are their representation in the construction workforce in general and in self-employment in particular. Where firms owned by minorities and women do exist in construction they are more likely than non-minority males to be in special trades rather than heavy and civil. They are also more likely to be sub-contractors than prime contractors. This does not appear to be because of a lack of an ability to expand to undertake these activities because it is well-known that small construction companies can expand rapidly as demand changes by hiring workers and renting equipment and making use of sub-contractors. A particular concern in construction is that it is hard for minority and women-owned firms to obtain capital, especially working capital, and this causes increased difficulties when bonds have to be posted. This is often made more difficult still when bonding firms are members of local construction associations. Also unions are pervasive in the sector and these unions have tended to be dominated by white males and have successfully controlled entry to craft jobs (Ashenfelter, 1972).

Minorities seeking employment in construction have traditionally been frustrated by entrenched industry networks that parcel out the better jobs to white males (Silver, 1986). The dominant explanation of persistent minority disadvantage in construction is succinctly summarized by Waldinger and Bailey: "Beneath the complicated regulations and proliferation of collective bargaining contracts lie a different reality, one dominated mainly by personal contracts and informal networks" (1991, p. 298). Even when minorities are able to acquire the skills required for entry into the construction trades, they are nonetheless outsiders in a world where insider networks shape access to the most attractive jobs.

Construction projects especially in the public sector are frequently subject to competitive bidding procedures. There is some evidence to suggest that there is collusion among bidders. Typically governments award contracts for construction of highways and buildings through low-price sealed bid auctions. On the day of the auction sealed bids are publicly reported along with complete information about the bidder's identity and bids and the project is awarded to the lowest bidder. In a study of bidding in highway construction projects in Florida from 1981-1986 Gupta (2002) found that bid prices fall as the number of bidders increase. Gupta concluded that 
"collusion is commonplace in these markets," (p.22, 2002). Gupta (2001) used the same data on Florida and showed that bid prices were higher when repeated interaction among firms is present. "Recurring market contact among rivals can facilitate bid-rigging by discouraging the ring members to stray from collusive agreement" (p.466, 2001). Porter and Zona (1993) examined auctions in New York State highway construction projects in Long Island in the early 1980s and found evidence of bid-rigging. Firms had many opportunities to communicate with each other and some firms even submitted joint bids. They found evidence that several ring members bid on most jobs but one was a serious bidder and others submitted phoney higher bids. Porter and Zona argue that "the characteristics of this particular market tend to facilitate collusion" (p. 524, 1993). Feinsten et al (1985) studied North Carolina highway contracts and found that non-competitive bidding led to a clustering of bids in an attempt to influence engineer's estimates of the cost of future lettings.

Ingraham (2005) considered the possibility of bidder-official collusion in contracting and examined bidder data from New York City School Construction Authority auctions relating to school repair and construction for the period 1990-1997. In April 1993 a scandal relating to bid rigging became public and a number of prosecutions ensued: officials in the School Construction Authority colluded with contractors by operating a "magic-number" scheme. The corrupt official who acted as auctioneer would collude with a contractor and at the bid letting meeting would keep his bid until last and knowing the low bid would read aloud a false bid just below this price. Then after the bid opening the official would use White-Out to doctor the bid form. Ingraham's regression analysis suggested that two auctioneers (other than the auctioneer already convicted) may have been guilty of such magic-number cheating. Furthermore, an analysis of specific bidders yielded weak evidence that two additional bidders may have been guilty of magic number cheating. Such collusive arrangements between longstanding industry participants make it very hard for new firms, especially those owned by women and minorities, to enter and be successful.

The mechanism by which firms owned by minorities and women are likely excluded is that without the collusion and rotating of bids, so that prices are above the competitive level, firms would subcontract to minority owned businesses and use minority employees to lower costs and undercut the prices of their rivals. But, of course if the firms are dividing up the business, taking turns winning with higher than competitive bids, they have no need to compete by using low-cost inputs, so the benefits of competition are not only lost regarding the price that the public pays for the construction projects, but the benefits of competition for minorities are lost as well. The role of the bid letting organizations is probably mostly to tacitly, or in many localities even overtly, go along with or encourage the combination of banking and bonding discrimination on the financial side with the established construction firms' discriminatory subcontracting and hiring decisions. It appears to be a complex confluence of actions by non-minorities that keeps minority owned businesses from establishing themselves and surviving. The discrimination likely results from a combination of actions from bid letting organizations, bidding companies, banks, and bonding companies. The bid letting organizations go along and probably in some locales even encourage the discrimination, the bidding firms in the club do not have competitive incentives to hire lower-cost subcontractors and employees, the banks and other financiers and bonding companies discriminate so they do not qualify as bidders on the financial side whatever their business qualifications. So, collusion aids discrimination in subcontracting and in 
employment. $^{5}$

Affirmative action programs in construction were implemented in the 1970s and 1980s in many jurisdictions, at the local, state and federal level, to help overcome some of these problems (Blanchflower and Wainwright, 2005; Chay and Fairlie, 1998). During this period then the proportion of public sector construction dollars going to firms owned by women and minorities increased. One thing that makes construction an attractive sector for affirmative action is the relatively large importance of the government in that sector - hence more leverage. Total spending on construction in construction spending in February 2008 was estimated at a seasonally adjusted annual rate of $\$ 1,121.6$ billion. Of this $73.7 \%$ was private, made up of $40.7 \%$ private residential and 32.9\% private non-residential; of the remainder $24.5 \%$ state and local and $1.8 \%$ federal (Source: http://www.census.gov/const/www/prpage.html). The proportion of total construction accounted for by the public sector has increased recently, as the private residential sector has declined. ${ }^{6}$ Even in construction though, the private sector is far larger than the public sector. So even with affirmative action in place the public sector is still only a relatively small slice of the overall economy.

There is a presumption underlying all of this legislation that discrimination against minorities and women in business, and especially in the construction industries where much of the legislation has focused, continues to persist. Senator Lautenberg, for example, stated during the course of Senate hearings in relation to TEA-21.

"Jim Crow laws were wiped off the books over 30 years ago. However, their pernicious effects on the construction industry remain. Transportation construction has historically relied on the old boy network which, until the last decade, was almost exclusively a white, old boy network. ... This is an industry that relies heavily on business friendships and relationships established decades, sometimes generations, ago — years before minority-owned firms were even allowed to compete."7

The U.S. Supreme Court's decision in City of Richmond v. J.A. Croson Co., 488 U.S. 469 (1989), established the current constitutional contours of permissible race-based public contracting programs. Reversing long established law, the U.S. Supreme Court for the first time extended the highest level of judicial examination to legislation to benefit rather than injure the historic victims of discrimination. However benign the government's motive, race is now always so suspect a classification that its use must now pass the highest constitutional test of "strict scrutiny.”

\footnotetext{
${ }^{5}$ We thank John Scott for helpful discussion on these points.

6 In contrast in February 2004 private construction seasonally adjusted accounted for $77.6 \%$ and private residential $54.2 \%$ of total construction respectively - http://www.census.gov/const/C30/pr200402.xls. Private residential construction was \$696,019 millions in February 2006 compared with \$456,923 millions in February 2008. http://www.census.gov/const/C30/residentialsa.xls
}

${ }^{7}$ p. 5101 Federal Register / Vol. 64, No. 21 / Tuesday, February 2, 1999 / Rules and Regulations. 
In addition to the federal government many cities and states had adopted demand-side goals programs and supply-side technical assistance programs. Frequently these covered a range of minority groupings and often white females. After Croson, during the 1990s numerous city, state, and federal programs that had race conscious components were challenged in the courts and, in most cases, ruled unconstitutional. Important cases include: City of Richmond; City of Philadelphia; City of Columbus; Fulton County, Georgia (Atlanta); Dade County, Florida (Miami); King County, Washington (Seattle); Cook County, Illinois (Chicago); Hillsborough County, Florida (Ft. Lauderdale); the District of Columbia; the State of Ohio, the State of Florida, and the Michigan DOT. In some jurisdictions a settlement was reached before the courts ruled and the program was dropped entirely such as in the South Florida Water Management District, the City of Charlotte and the City of Memphis. At the end of the 1990s the State of Texas DOT added white males to its program effectively making the program raceneutral, while the State of Maryland and the City of Jacksonville adopted revised race-conscious programs. In other jurisdictions such as the City of Columbus and the New Jersey DOT race conscious programs were replaced with programs that were entirely race blind. ${ }^{8}$ Other jurisdictions dropped their programs for fear of being sued.

Since the turn of the millennium there have been a number of court cases that have reversed the immediate post-Croson trend finding affirmative action programs to be constitutional. These include Sherbrooke Turf v. Minnesota DOT and Gross Seed v. Nebraska DOT from 2003 that related to the federal DBE program. ${ }^{9}$ Here, the courts ruled that the U.S. Congress had established 'compelling interest' and that the state programs were 'narrowly tailored.' In both these cases the U.S. Department of Justice and the U.S. Department of Transportation acted as intervenors, with the U.S. government defending the programs. ${ }^{10}$ Recently the U.S. District Court in Illinois, in the case of Northern Contracting Inc vs. the State of Illinois Department of Transportation (IDOT), ruled in favor of IDOT, citing the findings in the Sherbrooke Turf case as precedent, finding a compelling need for IDOT's plan which was "narrowly tailored to the goal of remedying the effects of racial and gender discrimination within the construction industry." In a similar case relating to the federal DBE program of Western States Paving $v$. State of Washington Department of Transportation (WsDOT), the court granted the defendant summary judgment dismissing the case but this was overturned in part on appeal to the $9^{\text {th }}$ Circuit Court of Appeals because WsDOT did not offer any evidence of discrimination in the Washington state construction industry and hence their program was not narrowly tailored. The $9^{\text {th }}$ Circuit did, however, find the DBE Program constitutional on its face.

\footnotetext{
${ }^{8}$ Whether affirmative action procurement programs that benefit women are subject to the lesser constitutional standard of 'intermediate scrutiny' has yet to be settled by the Supreme Court.

${ }^{9}$ Sherbrooke Turf, Inc. v. Minnesota Department of Transportation, et al, No.02-1665 (8 ${ }^{\text {th }}$ Cir. October 6, 2003) (Sherbrooke III), and Gross Seed Company v. Nebraska Department of Roads, et al, No. 02-3016 (8 ${ }^{\text {th }}$ Cir. October 6, 2003).

10 Appellee briefs filed by the U.S. Government in the district court in Western States, and in both the district and the $8^{\text {th }}$ Circuit Court of Appeal in Sherbrooke Turf and Gross Seed, along with the court decisions are available at http://www.usdoj.gov/crt/app/briefs_aa.htm

${ }^{11}$ Northern Contracting Inc v. the State of Illinois Department of Transportation (N.D., Il.), No. 00C4515 September $8^{\text {th }}$ 2005, p. 52.
} 
Two further cases relate to programs established not by the federal government with the approval of Congress, but by two cities - Denver and Chicago. In Concrete Works v. the City and County of Denver ${ }^{12}$ and in Builders Association of Greater Chicago (BAGC) v. City of Chicago affirmative action programs for MWBEs in construction were challenged as unconstitutional. The defendants did not have the benefit of arguing that Congress had established compelling interest and thus had a higher bar to reach since they had to establish compelling interest themselves within their own jurisdictions. Despite this, after lengthy trials, defendants in both cases successfully argued they had established a compelling interest in having their programs and in the Concrete Works case, after a decision of the $10^{\text {th }}$ Circuit Court of Appeals overturning the lower court's decision, that the program was narrowly tailored. ${ }^{13}$ The U.S. Supreme Court refused to overturn the $8^{\text {th }}$ and $10^{\text {th }}$ Circuit Appeals Court decisions respectively in Concrete Works, Sherbrooke Turf and Gross Seed by refusing to grant writs of certiorari. In the Concrete Works case, however, Justices Scalia and Rehnquist wrote a dissent from denial of certiorari. ${ }^{14}$ In the BAGC case the district court temporarily enjoined the program but in December 2003 Judge Moran ruled the City of Chicago had a 'compelling interest' in eradicating discrimination and permitted it to take steps to narrowly tailor its program, which it did a few months later when it introduced a new program. ${ }^{15}$

As part of these legal cases the defendants provided anecdotal evidence from the owners of MWBEs to the courts on discriminatory networks in contracting. This evidence is of particular interest as it was provided under oath under threat of perjury. The Appeals Court in the Concrete Works case summarised the anecdotal evidence of discrimination in construction in Denver in graphic detail as follows.

\footnotetext{
12 The City of Denver created an affirmative action ordinance establishing participation goals for minority- and women-owned contractors on certain City construction and design projects. A non-minority-owned firm challenged the constitutionality of this ordinance in 1992. In 1993, the district court's grant of summary judgment in favor of Denver was reversed on appeal and the case was remanded for trial. A bench trial was held in and in 2000, the district court enjoined Denver from enforcing the ordinance, thus halting the affirmative action program. Denver appealed, and on February 10, 2003 the 10th Circuit Court of Appeals overturned the 2000 ruling and upheld Denver's program. On November 17, 2003 the U.S. Supreme Court rejected a constitutional challenge to the same Denver program, letting the 10th Circuit's ruling stand.
}

13 Initially the trial court in Concrete Works found the program unconstitutional but the district court's decision was overturned by the $10^{\text {th }}$ Circuit Court of Appeals. In both the Gross Seed and Sherbrooke Turf cases the $8^{\text {th }}$ Circuit Court of Appeals, in an opinion where it consolidated the two cases, upheld the lower court's decision that Congress had established compelling interest for the programs and that defendants had established them to be narrowly tailored.

14 In Concrete Works the U.S. government filed amicus briefs on the side of the City and County of Denver with the $10^{\text {th }}$ Court of Appeals opposing the district court's decision declaring the program unconstitutional. See http://www.usdoj.gov/crt/briefs/concrete.htm. The $10^{\text {th }}$ Circuit Court of Appeals decision is available at http://www.usdoj.gov/crt/app/briefs_aa.htm. The U.S. Supreme Court dissent by Scalia and Rehnquist in Concrete Works is available at www.supremecourtus.gov/opinions/03pdf/02-1673.pdf.

15 The author acted as defendant's expert at trial in Concrete Works, Sherbrooke Turf, Gross Seed and BAGC. 
"The district court's memorandum and order contains a comprehensive synopsis of the anecdotal evidence presented by Denver at trial.... That evidence was extensive and included the testimony of the senior vice-president of a large, majority-owned construction firm who stated that when he worked in Denver, he received credible complaints from minority and women-owned construction firms that they were subject to different work rules than majority-owned firms. He also testified that he frequently observed graffiti containing racial or gender epithets written on job sites in the Denver metropolitan area. Further, he stated that he believed, based on his personal experiences, that many majority-owned firms refused to hire minority or women-owned subcontractors because they believed those firms were not competent.

Several M/WBE witnesses testified that they experienced difficulty prequalifying for private sector projects and projects with the City and other governmental entities in Colorado.... One individual testified that her company was required to pre-qualify for a private sector project while no similar requirement was imposed on majority-owned firms. Several others testified that they attempted to pre-qualify for projects but their applications were denied even though they met the prequalification requirements.

Other MWBEs testified that their bids were rejected even when they were the lowest bidder; that they believed they were paid more slowly than majority-owned firms on both City projects and private sector projects; that they were charged more for supplies and materials; that they were required to do additional work not part of the subcontracting arrangement; and that they found it difficult to join unions and trade associations. .... There was extensive testimony detailing the difficulties MWBEs experienced in obtaining lines of credit. One WBE testified that she was given a false explanation of why her loan was declined; another testified that the lending institution required the co-signature of her husband even though her husband, who also owned a construction firm, was not required to obtain her co-signature; a third testified that the bank required her father to be involved in the lending negotiations.

The most poignant anecdotal testimony involved recitations of racially- and gendermotivated harassment experienced by MWBEs at work sites. Women were called "bitches" and Blacks were called " $n^{* * * * * *} \mathrm{r}$ " or "dumb $\mathrm{n}^{* * * * * *} \mathrm{r}$." One seventy-three year old truck driver was called a "dumb, f-ing Mexican." Even more disturbing was the testimony that minority and female employees working on construction projects were physically assaulted and fondled, spat upon with chewing tobacco, and pelted with two-inch bolts thrown by males from a height of eighty feet." (Decision of the United States Court of Appeals $10^{\text {th }}$ Circuit overturning the district court decision that the Ordinance was unconstitutional." Concrete Works of Colorado., Inc. v. Denver, 86 F. Supp. 2d 1042 (D. Colo. Mar. 7, 2000). ${ }^{16}$

In addition owners of MWBEs reported in a number of jurisdictions that, even though they had performed successfully on public sector projects with goals they were not hired on private sector jobs without goals. For example, Judge Moran in his decision in the BAGC case summarized

${ }^{16}$ Available at http://www.usdoj.gov/crt/app/briefs aa.htm 
some of the anecdotal testimony as follows. ${ }^{17}$

"A pervasive theme of that testimony was that the MWBE firm was not solicited, or seldom solicited, for non-goals work, even though it was eager and available to do that work. Another was a METRA survey of MWBEs in which approximately $50 \%$ of those responding reported that they were seldom or never solicited for non-goals work". Moran, (2003). ${ }^{18}$

There is evidence since the 1980s in the United States that race and gender conscious affirmative action programs in construction and elsewhere can have a substantial impact. Enchautegui et al (1997) found that there are substantial disparities between the share of public contract dollars received by minority-owned firms and the share of all firms that they represent. The difference in these disparities is especially marked between jurisdictions which have affirmative action programs and those that have never had them or removed them. The disparities are much less where affirmative action programs exist.

Chay and Fairlie (1998) examined whether the set-aside programs established in many of the largest U.S. cities during the 1980s had an impact on the self-employment rates of blacks and whites. Their analysis was based on data from the Current Population Survey for 1979-1988. They stopped at 1988 since the 1989 Croson decision led to the dismantling of set-aside programs in many cities. They had some difficulty in ascertaining the exact starting dates of a number of the programs because there were inconsistencies in the data sources used. The paper examined what happened to self-employment rates when programs were introduced. They found that self-employment rates in construction for black men increased from about $12 \%$ before the programs were introduced to about $18 \%$ after. On the other hand, rates for white men were relatively stable before and after the programs were passed. Chay and Fairlie argued that "these figures provide strong evidence that set-aside programs worked".

Given the existence of Prevailing Wage Laws ${ }^{19}$ and widespread affirmative action programs it is of interest to determine whether the position of women and minorities in the construction sector has improved or worsened over time. It is very difficult to obtain any precise time line on the implementation of the various programs over time given that there is no definitive data source. Hence, in what follows I examine the change in self-employment post-Croson, which occurred in 1989 as well as post 2000 when affirmative action programs in construction appear to have received a new lease of life.

\footnotetext{
${ }^{17}$ Decision in Builder's Association of Greater Chicago vs. City of Chicago in the US District Court for the Northern District of Illinois Eastern Division (96C1122) by Judge James B. Moran December $29^{\text {th }} 2003$.

${ }^{18}$ Chicago METRA oversees all commuter rail operations in the 3,700 square mile northeastern Illinois region, with responsibility for day-to-day operations, fare and service levels, capital improvements and planning see www.metrarail.com

${ }^{19}$ Prevailing Wage Laws (PWLS) exist at the federal level and in addition the majority of states have their own PWLs. The intent of such legislation is primarily to protect the local wage rates in construction. These laws appear to have only small impacts on construction labor markets (Kessler and Katz, 2001).
} 


\subsection{Liquidity constraints}

In work based on U.S. micro data at the level of the individual, Evans and Leighton (1989), and Evans and Jovanovic (1989), have argued formally that entrepreneurs face liquidity constraints. The authors use the National Longitudinal Survey of Young Men for 1966-1981, and the Current Population Surveys for 1968-1987. The key test shows that, all else remaining equal, people with greater family assets are more likely to switch to self-employment from employment. This asset variable enters probit equations significantly and with a quadratic form. Although Evans and his collaborators draw the conclusion that capital and liquidity constraints bind, this claim is open to the objection that other interpretations of their correlation are feasible. One possibility, for example, is that inherently acquisitive individuals both start their own businesses and forego leisure to build up family assets. In this case, there would be a correlation between family assets and movement into self-employment even if capital constraints did not exist. A second possibility is that the correlation between family assets and the movement to self-employment arises because children tend to inherit family firms. Parker (2002) provides some much needed theory on whether banks ration enterprises.

Blanchflower and Oswald (1998), find that the probability of self-employment depends positively upon whether the individual ever received an inheritance or gift. This emerges from British data, the National Child Development Study; a birth cohort of children born in March 1958 who have been followed for the whole of their lives. Second, when directly questioned in interview surveys, potential entrepreneurs say that raising capital is their principal problem. Third, the self-employed report higher levels of job and life satisfaction than employees. Fourth, psychological test scores play only a small role. Work by Holtz-Eakin, Joulfaian and Rosen (1994a, 1994b), drew similar conclusions using different methods on U.S. data.

Hurst and Lusardi's paper (2004) - henceforth HL - reports some empirical patterns that challenge the conclusions reached by previous literature. Although the authors write that their findings should not be interpreted as complete lack of liquidity constraints, this seems to be the conclusion that many draw from their paper. Several papers have since raised doubts about both the HL findings and their interpretation. One of the HL pieces of evidence is that the entry probability into entrepreneurship as a function of wealth is rather flat apart from at the top of the wealth distribution - above the 95th percentile. Among several works challenging the interpretation that HL's results imply slack borrowing constraints, Fairlie and Krashinsky (2004) (FK) show that bifurcating the same PSID sample into workers who enter self-employment after job loss and those who do not, reveals steadily increasing entry rates as assets increase in both sub-samples. They argue that these two groups merit a separate analysis, because the two groups face different incentives, and thus have different solutions to the entrepreneurial decision (a point similar to the one made by Cagetti and De Nardi (2006) in the context of a structural model of entrepreneurship).

Another piece of evidence put forward by HL was that housing appreciation did not seem to increase entry into entrepreneurship. FK cast doubt on this finding using micro-data from matched Current Population Surveys (1993-2004). In their data set housing appreciation measured at the MSA-level indicates that a 10 percent annual increase in housing equity increases the mean probability of entrepreneurship by roughly 20 percent and that the effect is not concentrated at the upper tail of the distribution. Fairlie and Krashinsky's (2004) findings on 
the relationship between housing appreciation and entrepreneurship are consistent with the liquidity constraint hypothesis. Blanchflower and Shadforth (2007) showed that rising house prices, which freed up capital constraints, explain half of the recent increase in self-employment in the UK. This is consistent with Black et al (1996), for example, who found that a $10 \%$ rise in the value of unreleased net housing equity increases the number of new firm (VAT) registrations by some 5\%. Cowling and Mitchell (1997) estimate that in the UK a 10\% rise in housing wealth increased the proportion of the workforce in self-employment by $3 \%$.

Quadrini (2008) also points out that even in the case in which borrowing constraints have little effect on entry (because the entrepreneur starts the firm at a smaller than optimal size) they could still have a very large effect on firm growth and survival. In an interesting new paper Nykvist (2008) examined whether potential entrepreneurs face liquidity constraints using similar methods to HL on Swedish data. Nykvist concludes that liquidity constraints do play a significant role when determining transition into entrepreneurship in Sweden. Magri (2008) studies similar questions for Italy, and also found that liquidity constraints affect entrepreneurial entry in Italy.

Broussard et al. (2003) found that the self-employed in the USA have between .2 and .4 more children compared to the non-self-employed. The authors argue that having more children can increase the likelihood that an inside family member will be a good match at running the business. One might also think that the existence of family businesses, which are particularly prevalent in construction, is a further way to overcome the existence of capital constraints. Transfers of firms within families will help to preserve the status quo and will work against the interests of minorities in general and blacks in particular who do not have as strong a history of business ownership as indigenous whites. Analogously, Hout and Rosen (2000) found that the offspring of self-employed fathers are more likely than others to become self-employed and argued that the historically low rates of self-employment among African-Americans and Latinos may contribute to their low contemporary rates.

Blanchflower, Oswald and Stutzer (2001) found that there is a strikingly large latent desire to be in charge of one's own business. There exists frustrated entrepreneurship on a huge scale in the U.S. and other OECD countries. In the U.S., seven out of ten people say they would prefer to be self-employed. This compares to an actual proportion of self-employed people in 2001 of 7.3 percent of the civilian labor force, which also shows that the proportion of the labor force that is self-employed has declined steadily since 1990 following a small increase in the rate from 1980 to 1990 (Fairlie and Meyer, 2000). ${ }^{20}$ This raises an important puzzle. Why do so few individuals in the U.S. and OECD manage to translate their preferences into action? Lack of start-up capital is one likely explanation. A further issue is whether lack of liquidity helps to explain the large racial differences in self-employment. We provide evidence on this below.

We now turn to explicitly consider the construction industry, which accounts for nearly one fifth of all self-employed workers. There is evidence of discrimination against minorities and women in that industry - by private firms and unions in particular. As a result of such discrimination a number of public authorities, at the federal, state and local levels, have implemented affirmative

\footnotetext{
${ }^{20}$ Fairlie and Meyer (2000) documented the fact that the self-employment rate for white men fell from 1910 to 1970 but then increased until 1990. That trend has continued to fall thereafter according to Table 2 post 1993.
} 
action programs. These programs have dominantly, but not exclusively, been in construction. The main reason for this is that construction dollars are the main part of discretionary public sector spending. Such programs have been subject to a number of legislative challenges that I discuss in some detail below.

\section{Empirical evidence on the incidence of self-employment}

In this section I concentrate on examining publicly available, nationally representative, microdata on individuals. I have data both on the unincorporated self-employed as well as the incorporated self-employed who receive wages and salaries but are not counted as part of the official self-employment rate in the U.S. government counts.

Table 2 presents new evidence on self-employment rates by race and gender for the period 19832006 using data from the Basic Monthly files of the Current Population Survey (BMCPS). ${ }^{21}$ Weighted estimates were obtained for each year and then averaged over groupings of years for all industries as well as for construction for white males, white females, African-Americans and Hispanics. Additional data are available for Asians/Pacific Islanders and Native Americans since 1992. Data are also presented from the 2006 American Community Survey (ACS). Data are presented for total self-employment which we define here as the sum of incorporated and unincorporated: this is in contrast to the official definition of self-employment which only counts the number of unincorporated self-employed. There is no hours cut-off here and the sample includes both the agricultural and non-agricultural sectors which partly explains why the rates reported here are somewhat higher than those reported by Fairlie (2004) who reports nonagricultural rates with a smaller subset of these exact data. The figures in the table are percentages so 3.6 in the top left of Table 2a should be interpreted as $7.4 \%$ of employed white females were self-employed, compared with $15.5 \%$ of white males, $3.6 \%$ of African-Americans and $7.8 \%$ of Hispanics. Table $2 \mathrm{~b}$ reports similar results for the construction industry alone. The main findings from the table are as follows.

1) The self-employment rate of white males is markedly higher than is the case of any other group.

2) Self-employment rates in construction are higher for all groups than the national average in all years.

3) Overall self-employment rates for white men, Native Americans and Hispanics have fallen overall. Construction self-employment rates have increased for all groups, although the smallest increases have been for white men, Native Americans and Hispanics.

\footnotetext{
${ }^{21}$ The Merged Outgoing Rotation Group files of the CPS (MORG) are a subset if the BMCPS files. Each household entering the CPS is administered 4 monthly interviews, then ignored for 8 months, then interviewed again for 4 months. Since 1979 only households in months 4 and 8 have been asked their usual weekly earnings and hours. These are the outgoing rotation groups. The BMCP includes all eight rotations and hence is four times larger than the MORGs. A consequence of this construction is that an individual appears only once in any file year but may reappear in the following year.
} 
4) The differential between the overall self-employment rates of white males and white females in construction has narrowed dramatically over time. The narrowing is more apparent than is found for 'all industries'.

5) The differential between the overall self-employment rates in construction of white males and blacks has narrowed but less than it has for white women.

6) The differential between the overall self-employment rates in construction of white males and Hispanics has widened over time.

7) Of particular note is that self-employment rates of blacks and Hispanics in construction rose during the 1980s and then declined after the Croson decision through the 1990s (Table 2B). These trends are not apparent in the aggregate self-employment data in Table 2A. They then started to rise again after the Concrete Works, BAGC, Gross Seed and Sherbrooke Turf cases that were decided since 2000. For example, self-employment rates for African-Americans rose from 10.0\% in 1983 to 17.3\% in 1991, fell to $12.1 \%$ in 2002 and then rose to $19.1 \%$ in 2006. For Hispanics self-employment rates rose from $11.1 \%$ in 1983 rose to $15.6 \%$ in 1993 , fell to $9.4 \%$ in 2002 and then rose to $13.2 \%$ in 2006. In contrast rates for white women rose during the 1980 s from $13.1 \%$ in 1983 to a high of $28.9 \%$ in 1994 but then declined to 22.9\% in 2000 and have been roughly steady since that time. This flattening coincides with concerns that firms owned by white women were fronts for white men, which have resulted in public authorities being increasingly cautious in their certification processes.

There is a growing body of econometric research that has examined the probability that a randomly sampled worker is self-employed, holding constant their characteristics, especially their location, age and schooling (see Blanchflower 2000, 2004 and Blanchflower and Shadforth, 2007 for summaries). Some of this research has also looked at the probability that workers will move into or out of self-employment and the likely reasons for this. The main results from this work are as follows. Self-employment is higher among men than women; among older workers than younger workers; and is particularly high in construction and retailing. It is also especially high among some immigrant groups such as Koreans and Laotians; it does vary by region and state being especially high in construction occupations, agriculture and retailing. The selfemployed are generally happier and more satisfied with their jobs than is the case for employees, in part perhaps as they do not need to commute and have much more control over their lives (Blanchflower, and Oswald 2004). They are also work longer hours (Blanchflower, 2004). There is also evidence that capital constraints bind and when lifted self-employment rises (Blanchflower and Oswald, 1998). There is little evidence to show that countries with higher self-employment rates do better than those with lower rates (Blanchflower and Shadforth, 2007). High proportions of employees say they would like to be self-employed (Blanchflower, Oswald and Stutzer, 2001). The distribution of self-employment earnings is generally greater than it is for wages and salaries - that is to say it has longer tails at both ends of the distribution (Blanchflower and Shadforth, 2007).

Table 3 reports econometric evidence from estimating the probability of an individual being selfemployed, holding constant their characteristics such as their education, age, race, ethnicity, 
gender, industry and location. The table reports the coefficients from a series of dprobits estimated in STATA, where the dependent variable is set to one if currently self-employed and zero if an employee, with the sample thus restricted to workers. ${ }^{22}$ Controls include education, age and its square and state. The results from forty-eight separate equations are reported, one for each of the twenty four years and separately for all industries (part A) and construction (part B). In total there are over twelve million observations, of which approximately 850,000 are in construction. The probability of being self-employed in the US rises with age, is higher for men than for women and for married people than for the unmarried, rises with education; is highest in construction, is lower among minorities but higher among migrants and is especially high in Montana and lowest in Delaware. ${ }^{23}$

All coefficients in Table 3 are highly significant, often with t-statistics above 50 for all industries. $^{24}$ The conclusions are similar to those obtained from the means reported in Table 2.

1) The probability of being self-employed, ceteris paribus, is higher for white males than for other groups, with this gap most apparent in construction.

2) In construction, the gap between white females, Asians and blacks white males has narrowed markedly over time.

3) The gap between white males and Native Americans and Hispanics has changed little over time.

4) In construction the regression adjusted gap between white men and African Americans has narrowed appreciably recently - from $10.9 \%$ in 2002 to $7.2 \%$ in 2006.

Tables 4 and 5 provide confirming evidence from two other data sources: the 2000 Census and the 2006 American Community Survey, which both report information relating to the main activity in the year prior to interview. There are nearly eight million data points in Table 4 and over one and three quarter million data points in Table 5. Each table has the same format with all industry equations in columns 1 and for construction in column 4. Separate regressions are also reported for the probability an individual is incorporated self-employed (columns 2 and 5 ) or unincorporated (columns 3 and 6). In the case of the incorporated the unincorporated are dropped from the analysis and vice versa. Controls are as in Table 3 - age and its square, state of

${ }^{22}$ The dprobit procedure in STATA fits maximum-likelihood probit models and is an alternative to probit. Rather than reporting the coefficients, dprobit reports the marginal effect, that is the change in the probability for an infinitesimal change in each independent, continuous variable and, by default, reports the discrete change in the probability for dummy variables.

${ }^{23}$ Example equations estimating the probability of being self-employed (dprobits) from the most recently available data for 2007 for the US private sector and for private construction using data from the Outgoing Rotation Group files of the CPS are reported in the Appendix.

${ }^{24}$ For example, for 2006 the coefficients and t-statistics in parentheses were as follows - white female -.037 (51.92); African-American -.060 (54.46); Native American -.044 (15.41); Asian/Pacific Islander -.020 (13.82) and Hispanic .044 (40.23). In construction for 2006 the results were: white females -.065 (11.94); blacks -.0718 (9.59); Native Americans -.109 (7.81); Asian/Pacific Islanders -.084 (7.31) and Hispanics -.105 (20.87). 
residence and schooling. Estimated results are very similar to those in Table 3 for 1999, as they are in Table 4 for 2005. In contrast to Table 2b there is some increase in the absolute size of the coefficients for white females as well as for blacks, Asians and Hispanics between 1999 and 2005 in construction.

It is also appropriate to consider not only the incidence of self-employment but also the earnings. Data on self-employment earnings are unavailable in the BMCPS, or the MORG files of the CPS but are available in the March surveys of the CPS known as the Annual Demographic Supplement. This file also contains the basic monthly demographic and labor force data relating to employment, earnings, and income and refer to the preceding year, although demographic data refer to the time of the survey. Sample sizes are much lower than previously with around 194,000 observations per annum. Information on self-employed earnings is available for approximately 6,000 cases per annum. I pool together a number of years to ensure adequate sample sizes. Self-employed earnings relate to the preceding year, so 2001 earnings are derived from the 2002 survey. I also supplement this information for construction with data on annual earnings in the year preceding interview from the 2000 Census and the 2006 ACS. Individuals who report zero or negative self-employment are excluded and thus the sample coverage is any individual who reported positive self-employment earnings in the preceding year collected at tax time.

Table 6 reports estimates of the log of annual self-employment earnings differentials between white females and minority groups and comparable white males. Columns 1 and 2 are for all industries for the periods 1978-1990 and 1991-2001 respectively. Columns 3 and 4 are for construction over the same periods while column 5 is for construction in 1999 and column 6 for construction in 2004. The dependent variable is the log of self-employment earnings, which deletes non-positive earnings, but makes interpretation easier. The sample then consists of any individual who reported positive self-employment earnings in the preceding year whether or not they also reported wages. White females, blacks and other minority groups have significantly lower self-employment earnings than white males with similar personal characteristics. This is true in the private sector as a whole and in construction using both the March CPS files, the 2000 Census and the 2006 ACS. There is some evidence that the size of the coefficient for blacks has increased over time, suggesting further disadvantage.

It is apparent that there remain considerable disparities in the self-employment rates of white males and minorities and women. These differences are especially pronounced in construction. It appears that there was some improvement in the gap in self-employment rates between white men and blacks and Hispanics in particular during the 1980s and early 1990s when affirmative action programs were implemented by many public sector jurisdictions. Subsequent to the US Supreme Court decision in Croson in 1989 there was some widening again of this gap. Subsequent to a number of cases that occurred in the early 2000s that declared such programs constitutional, the gap has started to narrow once again.

\section{Liquidity constraints}

One important impediment to minority entrepreneurship is lack of capital. As noted by Nobel Laureate Kenneth Arrow. 
"Racial discrimination pervades every aspect of a society in which it is found. It is found above all in attitudes of both races, but also in social relations, in intermarriage, in residential location, and frequently in legal barriers. It is also found in levels of economic accomplishment; that is income, wages, prices paid, and credit extended" (1998, p.91 italics added)

Blanchflower, Levine and Zimmerman (2003) examined the availability of credit to minority and female-owned small businesses using data from the 1993 and 1998 National Surveys of Small Business Finances conducted by the Reserve Board of Governors. They demonstrated that loan denial probabilities for African-American owned firms were approximately double those for comparable white-owned firms in both sweeps of the survey. Even when African-Americans were able to obtain loans they had to pay higher interest rates. Comparable but smaller effects were found for Hispanics. These differences were not explained by differences in creditworthiness or other observables. Such differences disappeared when the use of credit cards was examined, where the banks were unaware of the race of the applicant. The authors found that firms owned by minorities are discriminated against in the credit market. Similar results were found by Cavalluzzo, Cavalluzzo and Wolken (2002).

A recent study published by the U.S. Chamber of Commerce (2005) confirms the findings in Blanchflower, Levine and Zimmerman (2003). The survey was conducted in March and April 2005 and detailed the financing problems experienced by small business owners, 95\% of whom had less than 100 employees: 1080 business owners were interviewed and reported that minority businesses rely heavily on credit cards to fund their businesses, often do not apply for credit, even though they need it, for fear of being denied and were especially likely to need working capital. In particular they report that availability of credit is their top problem, exactly as reported by Blanchflower et al (2003). The biggest difference in responses between minorities and Caucasian men and women was availability of credit: 19\% of Caucasian males report credit as their top problem compared with $54 \%$ for minority males - a 35 percentage point difference. There was a 15 percentage point difference for women. In no other category is there more than a 10 percentage point difference for men or women.

Table 7 updates the analysis in Blanchflower et al (2003) using data from the 2003 Survey of Small Business Finances, once again conducted by the Reserve Board of Governors. ${ }^{25}$ The dependent variable here is whether or not a loan was denied. As in earlier sweeps there was considerable variation by race and gender. The weighted means were as follows. Denial rates for firms owned by blacks are nearly six times higher than for firms owned by white males.

$\begin{array}{lcr} & \text { \% denied } & \mathrm{N} \\ \text { White males } & 11.8 & 1460 \\ \text { White females } & 14.8 & 209 \\ \text { Blacks } & 68.3 & 47 \\ \text { Asian } & 18.0 & 61 \\ \text { Hispanic } & 15.4 & 55\end{array}$

\footnotetext{
${ }^{25}$ To download the data and find survey details and documentation go to www.federalreserve.gov/pubs/oss/oss3/nssbftoc.htm
} 
Other races $\quad 37.5 \quad 22$

Total $\quad 14.8 \quad 1854$

As we move across the table control variable are added. There is consistent evidence that blackowned firms are discriminated in the credit market even after their characteristics, including their creditworthiness which in itself is likely impacted by discrimination, are controlled for. The effects for blacks are very similar to those reported by Blanchflower et al (2003) for both 1993 and 1998 - there has been no improvement at all over time for blacks. ${ }^{26}$ The coefficient for Hispanics is lower than for blacks but still substantial and more than double the probability a firm owned by a white male with the same characteristics would have a loan denied. There is now evidence that Asians are discriminated against in the credit market. The coefficient is close to significance at the $5 \%$ level on a one-tailed test. When interaction terms between construction and the race variables were included, they were statistically insignificant implying the results can be generalized to construction.

Table 7 reports the results of estimating a dprobit where the dependent variable is whether a business credit card is used to pay business expenses. As noted in Blanchflower, Levine and Zimmerman (2003) the application procedure for a business credit card is usually automated and the bank doesn't know the race of the applicant. If there were missing variables such as creditworthiness or some such characteristic unobserved to the econometrician the race variables should enter significantly in this equation. The proportion of firms with such cards is reported below - blacks and white females have a lower prevalence.

$\begin{array}{lcr} & \text { \% with card } & \mathrm{N} \\ \text { White males } & 49.7 & 3014 \\ \text { White females } & 43.2 & 670 \\ \text { Blacks } & 36.0 & 117 \\ \text { Asian } & 53.7 & 171 \\ \text { Hispanic } & 51.5 & 135 \\ \text { Other races } & 46.6 & 74 \\ \text { Total } & & \\ & 48.1 & 4181\end{array}$

In Table 7 there are significant coefficients in columns 1 and 2 for both blacks and white women. However, once suitable controls are included this result disappears. As in the denial equations interactions between race and the construction dummy were insignificant. The evidence on credit cards is of particular importance given that it is race, but not gender, blind. This is a nice 'natural experiment'. We would expect there to be differences in the availability of credit cards, credit balances etc between whites and blacks, for example, if there were remaining unobserved factors other than race. This suggests that there is potentially a more able pool of black applicants than white applicants out there. It remains unclear, for reasons discussed by

\footnotetext{
${ }^{26}$ With full sets of controls the coefficients for 1993 and 1998 for blacks were .23 and .31 and for Hispanics .03 and .22 respectively. They were not significant for other groups. Source Blanchflower et al (2003) Table 3.
} 
Blanchflower et al (2003) whether this implies higher or lower default rates, especially if the distribution of loan repayment probabilities is different.

Table 8 models the interest rate charged for those minority and female-owned firms who were able to successfully obtain a loan. As was found in earlier surveys, blacks are hit by a 'double whammy' in that they then have to pay one percentage higher rate on their loan than would firms owned by white males with identical characteristics. Hispanics have to pay one and a half percentage points higher. Asians pay half a point higher.

It appears that minorities are being discriminated against in the credit markets: when race is known they are unable to obtain loans and when they do obtain them they have to pay higher interest rates than is true of comparable white males. When race is unknown there is no disadvantage. Discrimination in the credit market remains for minority owners of small firms. Minority-owned firms have their loans denied when they shouldn't and have to pay higher rates of interest than appears appropriate given their characteristics.

\section{Conclusion}

The main findings of this paper are that there continue to be large disparities both in the incidence of self-employment and in the earnings obtained from it between white males and others. The differences are especially stark in construction despite the existence of a panoply of public sector procurement programs designed to improve the position of women and minorities. They were implemented at local, state and federal levels and have been subject to challenges in the courts. The US Supreme Court decision in the Croson case in 1989, however, made it very difficult to maintain such affirmative action programs and many were subsequently struck down by the courts. Where they did remain in existence many were watered down to the extent that many only had race-neutral components left. Since the turn of the millennium a number of cases have turned the tide in the other direction, with courts declaring a number of programs constitutional. Examples include cases relating to the City and County of Denver and the City of Chicago.

Overall, we have shown that there has been some deterioration over time in the relative position of African-Americans, white females and Asians compared to white males both nationally and in construction in the years after the Croson decision. Since the turn of the century, however, there has been some narrowing in the differentials in self-employment rates between white males and blacks and white females in construction. This appears to have been spurred by a number of court decisions - Gross Seed; Sherbrooke Turf, Concrete Works: BAGC and Northern Paving finding both federal, state and local public procurement programs in construction to be constitutional. In contrast the probability of being self-employed for Hispanics compared to white males has not improved.

It is clear, however, that despite some narrowing over time between white men and other groups substantial disparities still remain, especially in construction. Raw self-employment rates of white men in construction in 2006 were 28\% (Table 2b) compared with 21\% for white females, $17 \%$ for blacks and $13 \%$ for Hispanics. The gap between the earnings of white men and all groups other than Asians remains large. For example, in the 2006 ACS weighted selfemployment earnings of those with positive earnings was as follows: 


$\begin{array}{lcc}\text { White males } & \begin{array}{c}\text { Overall } \\ \$ 40,161\end{array} & \begin{array}{c}\text { Construction } \\ \$ 34,193\end{array} \\ \text { White females } & \$ 21,655 & \$ 26,000 \\ \text { Blacks } & \$ 22,149 & \$ 22,626 \\ \text { Native Americans } & \$ 20,260 & \$ 23,738 \\ \text { Asians } & \$ 37,954 & \$ 35,455 \\ \text { Other races } & \$ 22,874 & \$ 25,642 \\ \text { Hispanics } & \$ 25,696 & \$ 27,169 \\ \text { Average } & \$ 31,856 & \$ 31,884\end{array}$

Part of the differences between the self-employment rates of whites and minorities in general and blacks and Hispanics in particular, likely arises because of discrimination in the credit market. Firms owned by minorities in general and blacks in particular are much more likely to have their loans denied and pay higher interest than is the case for white males. It does not appear that these results are driven by missing variables such as creditworthiness. I examined the probability an individual would have a business credit card, where the application procedure is usually automated, and the bank does not know the race of the applicant. In such circumstances I could find no race effects, suggesting this is pure discrimination, confirming earlier work published in Blanchflower et al (2003) using older data from the same survey series.

Overall I conclude that there remain significant differences between the self-employment rates and earnings of whites and other racial groups. The observed effects are greatest for blacks and to a lesser degree for Hispanics. A good deal of the differences in self-employment rates of white men and minority-owned firms appears to arise because of lack of access to capital. There is some evidence that some improvement has been seen over time but remaining discrimination in the credit market against small firms owned by blacks in particular shows no signs of abating. 
Table 1. Self-employment as a \% of all non-agricultural employment

$\begin{array}{lcrrrrr}\text { Country } & 1960 \mathrm{~s} & 1970 \mathrm{~s} & 1980 \mathrm{~s} & 1990 \mathrm{~s} & 2000 \mathrm{~s} & 2005 \\ \text { Australia } & 10.0 & 10.5 & 12.2 & 12.2 & 11.5 & 11.4 \\ \text { Austria } & 13.3 & 10.6 & 7.3 & 6.8 & 8.1 & 8.8 \\ \text { Belgium } & 14.0 & 11.3 & 12.3 & 13.6 & - & - \\ \text { Canada } & 7.7 & 6.3 & 6.9 & 8.7 & 8.7 & 8.4 \\ \text { Czech Rep } & - & - & - & 11.7 & 15.4 & 15.2 \\ \text { Denmark } & 12.4 & 9.5 & 7.3 & 6.9 & 6.9 & 6.9 \\ \text { Finland } & - & 6.3 & 7.1 & 9.9 & 9.5 & 9.6 \\ \text { France } & 14.0 & 11.3 & 9.9 & 8.2 & 7.0 & 7.1 \\ \text { Germany } & 8.6 & 9.0 & 8.1 & 8.6 & 9.9 & 10.7 \\ \text { Greece } & - & 31.6 & 27.9 & 27.4 & 25.0 & 24.8 \\ \text { Hungary } & - & - & - & 15.3 & 12.3 & 12.4 \\ \text { Iceland } & 9.7 & 8.8 & 8.8 & 14.2 & 13.1 & 11.9 \\ \text { Ireland } & 10.3 & 10.2 & 11.3 & 13.3 & 12.8 & 12.9 \\ \text { Italy } & 25.7 & 21.9 & 21.0 & 22.8 & 23.3 & 24.2 \\ \text { Japan } & 14.5 & 13.9 & 13.0 & 10.2 & 8.8 & 8.5 \\ \text { Korea } & - & - & 25.5 & 23.1 & 24.2 & 23.9 \\ \text { Luxembourg } & 13.4 & 10.7 & 8.3 & 6.8 & 6.0 & 5.8 * \\ \text { Mexico } & - & 16.6 & 14.3 & 25.1 & 25.8 & 25.3 \\ \text { Netherlands } & - & 8.9 & 8.5 & 9.0 & 9.9 & - \\ \text { New Zealand } & 8.3 & 8.8 & 11.9 & 15.8 & 16.0 & 15.6 \\ \text { Norway } & - & 7.4 & 6.5 & 5.8 & 5.1 & 5.6 \\ \text { Poland } & 2.8 & 2.6 & 4.8 & 11.2 & 11.8 & 11.3 \\ \text { Portugal } & 14.9 & 12.4 & 16.3 & 18.3 & 17.2 & 16.4 \\ \text { Slovakia } & - & - & - & 6.6 & 9.8 & 12.6 \\ \text { Spain } & - & 15.7 & 17.2 & 17.8 & 15.4 & 15.2 \\ \text { Sweden } & 7.1 & 4.7 & 5.3 & 8.5 & 8.6 & 8.8 \\ \text { Turkey } & - & - & 26.0 & 25.2 & 22.9 & 23.2 \\ \text { UK } & 5.9 & 7.0 & 9.9 & 12.5 & 11.8 & 12.2 \\ \text { USA } & 8.1 & 6.9 & 7.5 & 7.3 & 6.7 & 6.8\end{array}$

Source: OECD Labour Force Statistics. *Luxembourg, 2004. 
Table 2a. Self-employment rates 1983-2006: by race and gender (\%) - all industries

\begin{tabular}{|c|c|c|c|c|c|c|}
\hline & $\begin{array}{l}\text { White } \\
\text { female }\end{array}$ & $\begin{array}{l}\text { White } \\
\text { male }\end{array}$ & Black & $\begin{array}{l}\text { Native } \\
\text { American }\end{array}$ & $\begin{array}{l}\text { Asian/ } \\
\text { Pacific Islander }\end{array}$ & Hispanics \\
\hline 1983 & $7.1 \%$ & $15.7 \%$ & $3.5 \%$ & & & $7.1 \%$ \\
\hline 1984 & $7.4 \%$ & $15.5 \%$ & $3.6 \%$ & & & $7.8 \%$ \\
\hline 1985 & $7.1 \%$ & $15.7 \%$ & $3.5 \%$ & & & $7.1 \%$ \\
\hline 1986 & $7.2 \%$ & $15.3 \%$ & $3.5 \%$ & & & $7.8 \%$ \\
\hline 1987 & $7.5 \%$ & $15.5 \%$ & $3.7 \%$ & & & $7.9 \%$ \\
\hline 1988 & $7.8 \%$ & $15.6 \%$ & $3.7 \%$ & & & $8.2 \%$ \\
\hline 1989 & $7.9 \%$ & $15.7 \%$ & $4.1 \%$ & $8.9 \%$ & $11.3 \%$ & $7.7 \%$ \\
\hline 1990 & $7.9 \%$ & $15.7 \%$ & $4.1 \%$ & $8.9 \%$ & $11.3 \%$ & $7.7 \%$ \\
\hline 1991 & $7.9 \%$ & $15.8 \%$ & $4.0 \%$ & $9.1 \%$ & $12.2 \%$ & $7.3 \%$ \\
\hline 1992 & $7.7 \%$ & $15.8 \%$ & $3.8 \%$ & $8.3 \%$ & $11.5 \%$ & $6.5 \%$ \\
\hline 1993 & $7.9 \%$ & $16.0 \%$ & $3.9 \%$ & $9.4 \%$ & $11.7 \%$ & $7.0 \%$ \\
\hline 1994 & $9.5 \%$ & $16.0 \%$ & $4.5 \%$ & $9.7 \%$ & $12.3 \%$ & $8.5 \%$ \\
\hline 1995 & $9.8 \%$ & $15.7 \%$ & $4.7 \%$ & $7.4 \%$ & $11.4 \%$ & $6.6 \%$ \\
\hline 1996 & $8.8 \%$ & $14.9 \%$ & $4.0 \%$ & $7.1 \%$ & $10.8 \%$ & $6.2 \%$ \\
\hline 1997 & $9.0 \%$ & $14.9 \%$ & $3.8 \%$ & $7.9 \%$ & $10.9 \%$ & $6.1 \%$ \\
\hline 1998 & $8.6 \%$ & $14.6 \%$ & $3.9 \%$ & $7.1 \%$ & $11.0 \%$ & $5.8 \%$ \\
\hline 1999 & $8.3 \%$ & $14.0 \%$ & $4.1 \%$ & $6.8 \%$ & $10.6 \%$ & $6.1 \%$ \\
\hline 2000 & $8.2 \%$ & $13.8 \%$ & $4.4 \%$ & $6.3 \%$ & $9.5 \%$ & $5.6 \%$ \\
\hline 2001 & $8.1 \%$ & $13.5 \%$ & $4.2 \%$ & $7.4 \%$ & $10.2 \%$ & $5.7 \%$ \\
\hline 2002 & $8.0 \%$ & $13.6 \%$ & $4.2 \%$ & $6.7 \%$ & $9.1 \%$ & $5.8 \%$ \\
\hline 2003 & $8.3 \%$ & $14.4 \%$ & $4.6 \%$ & $7.0 \%$ & $10.0 \%$ & $6.5 \%$ \\
\hline 2004 & $8.3 \%$ & $14.5 \%$ & $4.6 \%$ & $6.5 \%$ & $10.8 \%$ & $6.8 \%$ \\
\hline 2005 & $8.9 \%$ & $15.3 \%$ & $5.4 \%$ & $7.6 \%$ & $10.9 \%$ & $7.2 \%$ \\
\hline 2006 & $8.9 \%$ & $15.2 \%$ & $5.5 \%$ & $8.2 \%$ & $11.9 \%$ & $7.6 \%$ \\
\hline 2006 ACS & $8.3 \%$ & $14.4 \%$ & $5.1 \%$ & $7.2 \%$ & $10.2 \%$ & $8.5 \%$ \\
\hline
\end{tabular}

Source: Basic Monthly files of the Current Population Surveys (weighted) and 2006 ACS

Notes: workers only so the self-employment rate is defined as being one if self-employed, zero if an employee. 
Table 2b. Self-employment rates 1983-2006: by race and gender (\%) - construction

\begin{tabular}{|c|c|c|c|c|c|c|}
\hline & $\begin{array}{l}\text { White } \\
\text { female }\end{array}$ & $\begin{array}{l}\text { White } \\
\text { male }\end{array}$ & Black & $\begin{array}{l}\text { Native } \\
\text { American }\end{array}$ & $\begin{array}{l}\text { Asian/ } \\
\text { Pacific Islander }\end{array}$ & Hispanics \\
\hline 1983 & $13.1 \%$ & $24.3 \%$ & $10.0 \%$ & & & $11.1 \%$ \\
\hline 1984 & $16.2 \%$ & $23.9 \%$ & $12.7 \%$ & & & $12.4 \%$ \\
\hline 1985 & $15.1 \%$ & $24.4 \%$ & $12.2 \%$ & & & $12.4 \%$ \\
\hline 1986 & $14.6 \%$ & $24.4 \%$ & $13.0 \%$ & & & $12.7 \%$ \\
\hline 1987 & $15.2 \%$ & $24.9 \%$ & $13.2 \%$ & & & $12.4 \%$ \\
\hline 1988 & $16.8 \%$ & $25.4 \%$ & $11.6 \%$ & & & $13.2 \%$ \\
\hline 1989 & $18.8 \%$ & $25.2 \%$ & $11.3 \%$ & $16.5 \%$ & $13.3 \%$ & $13.9 \%$ \\
\hline 1990 & $18.9 \%$ & $26.0 \%$ & $15.7 \%$ & $18.2 \%$ & $12.4 \%$ & $11.4 \%$ \\
\hline 1991 & $18.6 \%$ & $26.4 \%$ & $17.3 \%$ & $19.6 \%$ & $18.2 \%$ & $12.8 \%$ \\
\hline 1992 & $19.6 \%$ & $27.1 \%$ & $15.8 \%$ & $15.2 \%$ & $15.7 \%$ & $14.3 \%$ \\
\hline 1993 & $22.0 \%$ & $28.3 \%$ & $15.0 \%$ & $17.2 \%$ & $14.1 \%$ & $15.6 \%$ \\
\hline 1994 & $28.9 \%$ & $28.0 \%$ & $14.2 \%$ & $17.7 \%$ & $18.0 \%$ & $14.1 \%$ \\
\hline 1995 & $26.2 \%$ & $26.7 \%$ & $13.5 \%$ & $10.5 \%$ & $21.7 \%$ & $13.2 \%$ \\
\hline 1996 & $25.0 \%$ & $26.6 \%$ & $13.9 \%$ & $16.1 \%$ & $21.7 \%$ & $13.0 \%$ \\
\hline 1997 & $24.2 \%$ & $26.7 \%$ & $14.3 \%$ & $18.8 \%$ & $20.8 \%$ & $12.1 \%$ \\
\hline 1998 & $23.5 \%$ & $27.1 \%$ & $14.0 \%$ & $19.7 \%$ & $19.6 \%$ & $10.5 \%$ \\
\hline 1999 & $20.7 \%$ & $26.2 \%$ & $13.8 \%$ & $12.5 \%$ & $18.2 \%$ & $12.1 \%$ \\
\hline 2000 & $20.9 \%$ & $26.0 \%$ & $14.8 \%$ & $11.7 \%$ & $17.6 \%$ & $11.1 \%$ \\
\hline 2001 & $22.9 \%$ & $24.7 \%$ & $13.0 \%$ & $18.4 \%$ & $19.6 \%$ & $10.0 \%$ \\
\hline 2002 & $22.2 \%$ & $24.9 \%$ & $12.1 \%$ & $11.9 \%$ & $16.1 \%$ & $9.4 \%$ \\
\hline 2003 & $21.5 \%$ & $27.1 \%$ & $17.7 \%$ & $16.9 \%$ & $17.6 \%$ & $11.7 \%$ \\
\hline 2004 & $20.1 \%$ & $28.1 \%$ & $17.1 \%$ & $15.1 \%$ & $23.0 \%$ & $14.3 \%$ \\
\hline 2005 & $20.8 \%$ & $27.2 \%$ & $19.5 \%$ & $16.2 \%$ & $24.6 \%$ & $13.0 \%$ \\
\hline 2006 & $22.7 \%$ & $27.8 \%$ & $19.1 \%$ & $17.6 \%$ & $24.4 \%$ & $13.2 \%$ \\
\hline 2006ACS & $20.7 \%$ & $28.4 \%$ & $17.7 \%$ & $17.7 \%$ & $25.5 \%$ & $14.6 \%$ \\
\hline
\end{tabular}

Source: Basic Monthly Surveys of the Current Population Surveys and the 2006 ACS

Notes: workers only so the self-employment rate is defined as being one if self-employed, zero if an employee. 
Table 3a. Regression adjusted race and gender effects - all industries (weighted)

$\begin{array}{lccccc} & \text { White female } & \text { Black } & \begin{array}{c}\text { Native } \\ \text { Americans }\end{array} & \begin{array}{c}\text { Asians/ } \\ \text { Pacific } \\ \text { islanders }\end{array} & \text { Hispanics } \\ 1983 & -.0627 & -.0800 & & & -.0506 \\ 1984 & -.0600 & -.0788 & & & -.0441 \\ 1985 & -.0560 & -.0761 & & & -.0428 \\ 1986 & -.0561 & -.0758 & & & -.0389 \\ 1987 & -.0545 & -.0762 & & & -.0396 \\ 1988 & -.0535 & -.0773 & & & -.0404 \\ 1989 & -.0505 & -.0776 & & & -.0443 \\ 1990 & -.0515 & -.0738 & & & -.0376 \\ 1991 & -.0517 & -.0745 & & -.0419 \\ 1992 & -.0507 & -.0752 & -.0447 & -.0279 & -.0495 \\ 1993 & -.0505 & -.0742 & -.0418 & -.0271 & -.0462 \\ 1994 & -.0408 & -.0815 & -.0492 & -.0235 & -.0413 \\ 1995 & -.0368 & -.0761 & -.0580 & -.0262 & -.0540 \\ 1996 & -.0377 & -.0737 & -.0529 & -.0270 & -.0533 \\ 1997 & -.0356 & -.0740 & -.0439 & -.0280 & -.0529 \\ 1998 & -.0354 & -.0704 & -.0463 & -.0240 & -.0516 \\ 1999 & -.0359 & -.0668 & -.0415 & -.0231 & -.0475 \\ 2000 & -.0352 & -.0613 & -.0490 & -.0286 & -.0495 \\ 2001 & -.0331 & -.0603 & -.0435 & -.0232 & -.0468 \\ 2002 & -.0333 & -.0603 & -.0483 & -.0288 & -.0419 \\ 2003 & -.0367 & -.0630 & -.0453 & -.0297 & -.0454 \\ 2004 & -.0385 & -.0636 & -.0504 & -.0283 & -.0463 \\ 2005 & -.0369 & -.0610 & -.0478 & -.0269 & -.0462 \\ 2006 & -.0366 & -.0599 & -.0443 & -.0204 & -.0444 \\ & & & & & \end{array}$

Source: Basic Monthly Surveys of the Current Population Surveys http://www.nber.org/data/cps_basic.html

Notes: these are the estimated coefficients from separate dprobits for each year. Controls include age and its square, 50 state dummies and fifteen schooling dummies thereafter. Average yearly sample size is 845,632 . Total number of observations is $12,394,490$.

All coefficients significant well above conventional levels. 
Table 3b. Regression adjusted race and gender effects - construction (weighted)

White female Black $\begin{gathered}\text { Native } \\ \text { Americans }\end{gathered} \begin{gathered}\text { Asians/ } \\ \text { Pacific } \\ \text { islanders }\end{gathered} \quad$ Hispanics

$\begin{array}{llllll}1983 & -.1133 & -.1237 & & & -.0977 \\ 1984 & -.0935 & -.1013 & & & -.0823 \\ 1985 & -.1039 & -.1124 & & & -.0650 \\ 1986 & -.1024 & -.1117 & & & -.0639 \\ 1987 & -.1024 & -.1085 & & & -.0799 \\ 1988 & -.1043 & -.1242 & & & -.0678 \\ 1989 & -.0876 & -.1247 & & & -.0558 \\ 1990 & -.0813 & -.1053 & & & -.0853 \\ 1991 & -.0829 & -.0859 & & & -.0804 \\ 1992 & -.0935 & -.0993 & -.1055 & -.1354 & -.0685 \\ 1993 & -.0827 & -.1153 & -.0815 & -.1545 & -.0609 \\ 1994 & -.0013 & -.1299 & -.1016 & -.1095 & -.0817 \\ 1995 & -.0140 & -.1268 & -.1659 & -.0361 & -.1017 \\ 1996 & -.0373 & -.1136 & -.1086 & -.0923 & -.0943 \\ 1997 & -.0406 & -.1144 & -.0804 & -.0912 & -.0953 \\ 1998 & -.0462 & -.1211 & -.0598 & -.0912 & -.1217 \\ 1999 & -.0532 & -.1126 & -.0976 & -.1017 & -.0971 \\ 2000 & -.0547 & -.0958 & -.1344 & -.0902 & -.0967 \\ 2001 & -.0369 & -.1048 & -.0644 & -.0818 & -.0993 \\ 2002 & -.0386 & -.1094 & -.0977 & -.1007 & -.1035 \\ 2003 & -.0670 & -.0953 & -.0834 & -.1170 & -.1103 \\ 2004 & -.0789 & -.0939 & -.1089 & -.0741 & -.0841 \\ 2005 & -.0674 & -.0761 & -.1027 & -.0698 & -.0928 \\ 2006 & -.0652 & -.0718 & -.1089 & -.0837 & -.1050\end{array}$

Source: Basic Monthly Surveys of the Current Population Surveys http://www.nber.org/data/cps_basic.html

Notes: these are the estimated coefficients from separate dprobits for each year. Controls include age and its square, 50 state dummies and fifteen schooling dummies thereafter. Average yearly sample size is 57,889 . Total number of observations is 860,169 .

All coefficients significant well above conventional levels. 
Table 4. Self-employment dprobits, 1999

\begin{tabular}{|c|c|c|c|c|c|c|}
\hline & $(1)$ & $(2)$ & (3) & $(4)$ & (5) & $(6)$ \\
\hline White female & $-.0321(149.71)$ & $-.0162(149.77)$ & $-.0163(86.91)$ & $-.0715(38.11)$ & $.0007(0.68)$ & $-.0840(48.90)$ \\
\hline Black & $-.0546(174.53)$ & -.0183 (120.79) & -.0360 (130.92) & -.0910 (42.79) & $-.0374(29.26)$ & $-.0659(34.51)$ \\
\hline Native American & $-.0408(50.24)$ & $-.0136(33.48)$ & $-.0273(39.12)$ & $-.0801(17.36)$ & $-.0280(9.88)$ & $-.0626(15.26)$ \\
\hline Asian & $-.0200(40.22)$ & $-.0028(11.54)$ & $-.0181(41.98)$ & $-.0400(7.70)$ & $-.0113(3.61)$ & $-.0338(7.15)$ \\
\hline Other race & -.0353 (92.97) & $-.0109(56.08)$ & $-.0248(76.05)$ & $-.0771(35.78)$ & $-.0226(16.35)$ & $-.0643(33.51)$ \\
\hline Hispanic & -.0349 (84.09) & $-.0104(50.30)$ & $-.0249(69.45)$ & -.0703 (29.35) & $-.0187(12.33)$ & $-.0599(28.00)$ \\
\hline Construction & .1216 (281.97) & .0385 (159.38) & .0959 (249.15) & $\mathrm{n} / \mathrm{a}$ & $\mathrm{n} / \mathrm{a}$ & $\mathrm{n} / \mathrm{a}$ \\
\hline Incorporated & No & Yes & No & No & Yes & No \\
\hline Unincorporated & No & No & Yes & No & No & Yes \\
\hline Construction & No & No & No & Yes & Yes & Yes \\
\hline Pseudo $\mathrm{R}^{2}$ & .0813 & .0922 & .0708 & .0598 & .0704 & .0556 \\
\hline $\mathrm{N}$ & $7,848,046$ & $7,317,467$ & $7,622,265$ & 565,500 & 473,873 & 528,916 \\
\hline
\end{tabular}

Source: 2000 Census.

Notes: All equations also include 15 highest qualification dummies, age and its square plus 50 state dummies. Workers only. T-statistics in parentheses. Self-employment relates to 1999. 
Table 5. Self-employment dprobits, 2005

\begin{tabular}{|c|c|c|c|c|c|c|}
\hline & (1) & (2) & (3) & (4) & (5) & (6) \\
\hline White female & $-.0369(75.11)$ & -.0195 (76.14) & $-.0199(45.13)$ & $-.0863(21.40)$ & $-.0090(3.60)$ & $-.0970(25.99)$ \\
\hline Black & -.0597 (79.97) & $-.0226(60.67)$ & $-.0374(55.13)$ & -.0955 (18.92) & $-.0525(16.61)$ & $-.0578(12.61)$ \\
\hline Native American & $-.0458(21.10)$ & $-.0188(17.09)$ & $-.0263(13.35)$ & $-.0816(7.02)$ & $-.0463(6.18)$ & $-.0500(4.78)$ \\
\hline Asian & $-.0248(23.81)$ & $-.0045(8.51)$ & $-.0230(24.48)$ & $-.0425(4.28)$ & $-.0141(2.23)$ & $-.0356(3.88)$ \\
\hline Other race & $-.0376(41.21)$ & $-.0159(33.36)$ & $-.0232(28.78)$ & $-.0758(16.15)$ & $-.0331(10.46)$ & $-.0565(13.40)$ \\
\hline Hispanic & $-.0365(39.25)$ & -.0138 (29.24) & $-.0242(29.14)$ & -.0905 (18.77) & $-.0402(12.62)$ & $-.0641(14.65)$ \\
\hline Construction & $.1482(150.23)$ & .0565 (94.23) & $.1106(124.24)$ & & & \\
\hline Incorporated & No & Yes & No & No & Yes & No \\
\hline Unincorporated & No & No & Yes & No & No & Yes \\
\hline Construction & No & No & No & Yes & Yes & Yes \\
\hline Pseudo $\mathrm{R}^{2}$ & .0837 & .1033 & .0712 & .0671 & .0872 & .0645 \\
\hline $\mathrm{N}$ & $1,764,847$ & $1,631,376$ & $1,644,671$ & 130,014 & 106,965 & 118,820 \\
\hline
\end{tabular}

Source: American Community Survey, 2006

Notes: All equations also include 15 highest qualification dummies, age and its square plus 50 state dummies. Workers only. Incorporated excludes the unincorporated and vice versa. T-statistics in parentheses. Self-employment relates to 2005. 
Table 6. Log Self Employment Earnings Equations, 1979-2004

\begin{tabular}{|c|c|c|c|c|c|c|}
\hline & $(1)$ & $(2)$ & (3) & $(4)$ & $(5)$ & $(6)$ \\
\hline & All & All & Construction & Construction & Construction & Construction \\
\hline & $1978-1990$ & 1991-2001 & $1978-1990$ & 1991-2001 & 1999 & 2005 \\
\hline \multirow[t]{2}{*}{ White female } & -.729 & -.617 & -.835 & -.839 & -.702 & -.562 \\
\hline & $(68.07)$ & $(31.34)$ & $(21.63)$ & $(15.73)$ & $(28.67)$ & $(14.04)$ \\
\hline \multirow[t]{2}{*}{ Black } & -.500 & -.591 & -.428 & -.323 & -.387 & -.639 \\
\hline & $(15.64)$ & $(14.85)$ & $(5.73)$ & $(2.40)$ & $(12.09)$ & $(13.75)$ \\
\hline \multirow[t]{2}{*}{ Hispanic } & -.278 & -.390 & -.252 & -.145 & -.146 & -.059 \\
\hline & $(9.46)$ & $(9.8)$ & (3.96) & $(1.38)$ & $(4.96)$ & $(1.31)$ \\
\hline \multirow[t]{2}{*}{ Other races } & -.328 & -.221 & -.208 & -.180 & -.160 & -.180 \\
\hline & $(8.29)$ & $(3.41)$ & $(1.79)$ & $(0.84)$ & $(5.08)$ & $(4.35)$ \\
\hline \multirow[t]{2}{*}{ Asian/Pacific Islanders } & & & & & .004 & -.265 \\
\hline & & & & & $(0.08)$ & (3.27) \\
\hline \multirow[t]{2}{*}{ Native Americans } & & & & & -.397 & -.467 \\
\hline & & & & & $(7.15)$ & $(4.54)$ \\
\hline Education controls (16) & No & Yes & No & Yes & Yes & Yes \\
\hline Year dummies (13) & Yes & Yes & Yes & Yes & No & No \\
\hline State dummies (51) & Yes & Yes & Yes & Yes & Yes & Yes \\
\hline Industry dummies (88) & Yes & Yes & No & No & No & No \\
\hline $\mathrm{N}$ & 82,094 & 55,639 & 12,577 & 8,446 & 64,188 & 23,052 \\
\hline Adjusted $\mathrm{R}^{2}$ & .177 & .128 & .077 & .064 & .064 & .044 \\
\hline
\end{tabular}

Notes: The percents indicate the percent difference in self-employment earnings between the indicated group and whites. Controls also include age, age squared and a full set of year dummies in columns 1-4 plus years of education in columns 1 and 3 . CPS data relate to the year preceding the survey, so the 1991 data are taken from the 1992 survey etc. T-statistics in parentheses.

Source: Annual Demographic (March) files of the Current Population Survey for 1979-2005, 2000 Census and 2006 American Community Survey. 
Table 7. Probabilities of denial, (Dprobit), 2003

\begin{tabular}{|c|c|c|c|c|c|c|}
\hline & (1) & $(2)$ & (3) & (4) & (5) & (6) \\
\hline Blacks & $.4882(8.07)$ & $.4540(7.43)$ & $.3675(6.08)$ & $.3142(5.44)$ & $.2964(5.25)$ & $.2861(5.01)$ \\
\hline Asians & $.0911(2.11)$ & $.0766(1.88)$ & $.0694(1.76)$ & $.0663(1.76)$ & .0666 (1.87) & .0659 (1.85) \\
\hline Hispanics & .1305 (2.79) & $.1143(2.59)$ & $.0866(2.11)$ & $.0812(2.08)$ & $.0893(2.34)$ & $.0953(2.26)$ \\
\hline Other races & $.1610(2.16)$ & .1254 (1.78) & $.1330(1.91)$ & .1312 (1.89) & .1037 (1.65) & .1045 (1.66) \\
\hline White women & $.0575(2.41)$ & $.0454(2.05)$ & .0389 (1.83) & $.0306(1.51)$ & $.0184(1.01)$ & $.0162(0.86)$ \\
\hline Employment size & & $-.0006(4.31)$ & -.0005 (3.79) & $-.0005(3.77)$ & $-.0005(4.14)$ & $-.0005(4.15)$ \\
\hline Firm bankrupt & & & .1996 (1.98) & $.1244(1.45)$ & .1024 (1.36) & .1006 (1.34) \\
\hline Firm delinquent & & & $.0629(3.62)$ & $.0215(1.32)$ & $.0136(0.93)$ & $.0135(0.92)$ \\
\hline Owner delinquent & & & $.1473(5.16)$ & $.1368(5.00)$ & .1379 (5.24) & .1383 (5.23) \\
\hline Owner bankrupt & & & .0993 (1.38) & $.0851(1.27)$ & $.0644(1.11)$ & .0664 (1.13) \\
\hline Owner judgments & & & $.0663(1.48)$ & $.0594(1.40)$ & $.0484(1.40)$ & $.0483(1.30)$ \\
\hline Construction*Blach & & & & & & $.1081(0.53)$ \\
\hline Construction*Hispa & & & & & & $-.0172(0.27)$ \\
\hline Construction*white & emale & & & & & $.0327(0.45)$ \\
\hline D \& B credit score & No & No & No & 5 & 5 & 5 \\
\hline Organization type & No & 9 & 9 & 9 & 9 & 9 \\
\hline Regional dummies & No & 9 & 9 & 9 & 9 & 9 \\
\hline Industry dummies & No & No & No & No & 38 & 38 \\
\hline Pseudo $\mathrm{R}^{2}$ & .0610 & .1048 & .1662 & .1931 & .2496 & .2500 \\
\hline $\mathrm{N}$ & 1854 & 1838 & 1838 & 1838 & 1838 & 1838 \\
\hline
\end{tabular}

Source: 2003 Survey of Small Business Finances. Excluded category white men. T-statistics in parentheses. Dependent variable is whether a loan was application was denied. First imputation method used. Denial rates below.

$\begin{array}{lcr} & \text { Rate (\%) } & \text { N } \\ \text { White males } & 11.8 & 1460 \\ \text { White females } & 14.8 & 209 \\ \text { Blacks } & 68.3 & 47 \\ \text { Asians } & 18.0 & 61 \\ \text { Hispanics } & 15.4 & 55 \\ \text { Other races } & 37.5 & 22 \\ \text { Total } & 14.8 & 1854\end{array}$


Table 8. Use of business credit cards (dprobit)

\begin{tabular}{|c|c|c|c|c|c|c|}
\hline & (1) & (2) & (3) & (4) & (5) & (6) \\
\hline Blacks & $-.149(3.16)$ & $-.131(2.75)$ & $-.086(1.77)$ & $-.039(0.78)$ & $-.027(0.53)$ & $-.008(0.14)$ \\
\hline Asians & $.028(0.71)$ & $.032(0.81)$ & $.020(0.49)$ & $.036(0.88)$ & $.041(1.00)$ & $.044(1.06)$ \\
\hline Hispanics & $-.010(0.24)$ & $-.001(0.03)$ & $.023(0.49)$ & $.034(0.76)$ & .036 (0.80) & $.060(1.24)$ \\
\hline Other races & $-.024(0.41)$ & $-.009(0.14)$ & $.021(0.34)$ & $.034(0.76)$ & $.019(0.31)$ & $.021(0.33)$ \\
\hline White women & $-.071(3.31)$ & $-.050(2.34)$ & $-.008(0.36)$ & $.002(0.09)$ & $.010(0.44)$ & $.020(0.83)$ \\
\hline Employment size & & .001 (8.93) & $.001(3.75)$ & $.001(3.50)$ & $.001(4.28)$ & $.001(4.23)$ \\
\hline Firm bankrupt & & & & $-.008(0.09)$ & $.007(0.07)$ & $.016(0.16)$ \\
\hline Firm delinquent & & & & $.072(2.94)$ & $.066(2.66)$ & $.069(2.77)$ \\
\hline Owner delinquent & & & & $-.088(2.82)$ & $-.090(2.83)$ & $-.094(2.97)$ \\
\hline Owner bankrupt & & & & $-.042(0.63)$ & $-.045(0.66)$ & $-.048(0.71)$ \\
\hline Owner judgments & & & & $-.014(0.22)$ & $-.005(0.09)$ & $-.006(0.10)$ \\
\hline Construction*Blach & & & & & & $-.282(1.31)$ \\
\hline Construction*Hisp & & & & & & $-.187(1.38)$ \\
\hline Construction*white & female & & & & & $-.128(1.37)$ \\
\hline D \& B credit score & No & No & No & 5 & 5 & 5 \\
\hline Organization type & No & No & 9 & 9 & 9 & 9 \\
\hline Regional dummies & No & No & 9 & 9 & 9 & 9 \\
\hline Industry dummies & No & No & No & No & 38 & 38 \\
\hline Pseudo R ${ }^{2}$ & .0036 & .0183 & .0703 & .0774 & .0884 & .0893 \\
\hline $\mathrm{N}$ & 4181 & 4181 & 4181 & 4181 & 4181 & 4181 \\
\hline
\end{tabular}

Source: 2003 Survey of Small Business Finances. Excluded category white men. T-statistics in parentheses. Dependent variable is the interest charged on the loan. First imputation method used. 
Table 9. Interest rates charged (OLS)

\begin{tabular}{|c|c|c|c|c|c|}
\hline & $(1)$ & $(2)$ & (3) & (4) & (5) \\
\hline Blacks & 1.6088 (3.01) & 1.0925 (2.14) & $1.2286(2.45)$ & $1.0532(2.11)$ & 1.2256 (2.39) \\
\hline Asians & .4652 (1.30) & $.5106(1.50)$ & .5234 (1.57) & $.5391(1.62)$ & $.4514(1.35)$ \\
\hline Hispanics & $1.6945(4.45)$ & $1.6462(4.54)$ & $1.5885(4.46)$ & $1.5272(4.30)$ & 1.5013 (3.81) \\
\hline Other races & $.4042(2.00)$ & .2294 (1.19) & $.1318(0.70)$ & $.0916(0.49)$ & $-.1281(0.22)$ \\
\hline White women & .0469 (0.08) & $.0210(0.04)$ & $-.0725(0.13)$ & $.0065(0.01)$ & .1591 (0.81) \\
\hline Fixed interest rate & & 1.6047 (13.23) & 1.4125 (11.63) & 1.3474 (11.01) & 1.3651 (11.12) \\
\hline Employment size & & & $-.0066(8.04)$ & $-.0060(7.13)$ & $-.0061(7.08)$ \\
\hline Construction*Black & & & & & $-3.7000(1.50)$ \\
\hline Construction*Hispa & & & & & $-.0084(0.01)$ \\
\hline Construction*white & female & & & & -.7233 (1.14) \\
\hline Organization type & No & No & No & Yes & Yes \\
\hline D \& B credit score & No & No & No & Yes & Yes \\
\hline Regional dummies & No & No & No & No & Yes \\
\hline Constant & 5.7552 & 5.0680 & 5.5118 & 6.2984 & 6.3818 \\
\hline Adjusted $\mathrm{R}^{2}$ & .0155 & .1073 & .1397 & .1521 & .1552 \\
\hline $\mathrm{N}$ & 1699 & 1699 & 1699 & 1699 & 1699 \\
\hline
\end{tabular}

Source: 2003 Survey of Small Business Finances. Notes: 8 organization type dummies and 5 Dun and Bradstreet credit core dummies are included in the final column. Excluded category white men. T-statistics in parentheses. Dependent variable is the interest charged on the loan. First imputation method used.

$\begin{array}{lrr} & \text { Rate (\%) } & \mathrm{N} \\ \text { White males } & 6.4 & 1366 \\ \text { White females } & 7.0 & 188 \\ \text { Blacks } & 10.1 & 24 \\ \text { Asians } & 6.6 & 55 \\ \text { Hispanics } & 8.9 & 48 \\ \text { Other races } & 7.1 & 18 \\ \text { Total } & 6.6 & 1699\end{array}$




\section{$\underline{\text { References }}$}

Arrow, K.J. (1998), 'What has economics to say about racial discrimination?', Journal of Economic Perspectives, 12(2), pp. 91-100.

Ashenfelter, O. (1972), 'Race discrimination and trade unionism', Journal of Political Economy, Volume 80, Issue 3, Part 1, May-June pp. pp. 435-464.

Bates, T., 'Small business viability in the urban ghetto,' Journal of Regional Science. 29(4): 62543 (1989).

Black, J., De Meza, D. and D. Jeffreys (1996), 'House prices, the supply of collateral, and the enterprise economy’, Economic Journal, 106, January, pp. 60-75.

Blanchflower, D.G. (2000), 'Self-employment in OECD countries', Labour Economics, 7, September, pp. 471-505.

Blanchflower, D.G. (2004), 'Self-Employment: more may not be better,' Swedish Economic Policy Review, 11(2), Fall, pp. 15-74

Blanchflower, D.G., P. Levine and D. Zimmerman (2003), 'Discrimination in the small business credit market,' Review of Economics and Statistics, 85(4); 930-943, November.

Blanchflower, D.G. and A.J. Oswald (1998), 'What makes an entrepreneur?', Journal of Labor Economics, January, 16(1), pp. 26-60.

Blanchflower, D.G. and A.J. Oswald (2008), 'What makes a young entrepreneur?', _forthcoming in International Handbook on Youth and Young Adulthood edited by Andy Furlong, in the Routledge International Handbook series.

Blanchflower, D. G., A.J. Oswald and A. Stutzer (2001), 'Latent entrepreneurship across nations,' European Economic Review, 45(4-6), May, pp. 680-691.

Blanchflower, D.G. and C. Shadforth (2007), 'Entrepreneurship in the UK', Foundations and Trends in Entrepreneurship, 3(4), pp. 257-364.

Blanchflower, D.G. and J. Wainwright (2005), 'An analysis of the impact of affirmative action programs on self-employment in the construction industry', National Bureau of Economic Research, Inc, NBER Working Papers \# 11793.

Broussard, N., R. Chami and G. Hess, (2003), '(Why) do self-employed parents have more children?', Working Paper, September.

Cagetti, M., and M. DeNardi (2006), 'Entrepreneurship, frictions and wealth', Journal of Political Economy, 114(5), 835-70. 
Cavalluzzo, K., L. Cavalluzzo and J. Wolken (2002), 'Competition, small business financing and discrimination: evidence from a new survey', Journal of Business, 75, October, pp.641-679.

Chay, K.Y. and R. W. Fairlie (1998), 'Minority business set-asides and black self-employment, Working Paper, December.

Cowling M, and P. Mitchell (1997), 'The evolution of UK self-employment: a study of government policy and the role of the macroeconomy', Manchester School of Economic and Social Studies, 65(4), September, pp. 427-442.

Devine, T.J. (1994), 'Changes in wage and salary returns to skill and the recent rise in female self-employment, American Economic Review, May, 84(2), pp. 108-113.

Dunn, T. A. and D.J. Holtz-Eakin (2000), 'Financial capital, human capital, and the transition to self-employment: evidence from intergenerational links,' Journal of Labor Economics, 18 (2): 282-305.

Enchautegui, M.E., M. Fix, P. Loprest, S. von der Lippe, and D. Wissoker (1997), Do MinorityOwned Businesses Get a Fair Share of Government Contracts? Washington, D.C.: Urban Institute.

Evans, D. and B. Jovanovic (1989), 'An estimated model of entrepreneurial choice under liquidity constraints', Journal of Political Economy, 97, pp. 808-827.

Evans, D. and L. Leighton (1989), 'Some empirical aspects of entrepreneurship', American Economic Review, 79, pp. 519-535.

Fairlie, R. W. (1999), 'The absence of the African-American owned business: an analysis of the dynamics of self-employment', Journal of Labor Economics, 17(1), pp. 80-108.

Fairlie, R. W. (2004), 'Recent trends in ethnic and racial self-employment, $\underline{\text { Small Business }}$ Economics, 23 (3), pp. 203-18.

Fairlie, R.W. and H.A. Krashinsky (2006), 'Liquidity constraints, household wealth and entrpreneurship revisited', Working Paper, University of California, Santa Cruz.

Fairlie, R.W. and B.D. Meyer (2000), 'Trends in self-employment among white and black men during the twentieth century', Journal of Human Resources, XXXV(4), pp. 643-669.

Fairlie, R.W. and A. Robb (2007a), Families, human capital, and small business: evidence from the Characteristics of Business Owners Survey', Industrial and Labor Relations Review, xxxxx.

Fairlie, R.W. and A. Robb (2007b), 'Why are black-owned businesses less successful than whiteowned businesses? he role of families, inheritances, and business human capital', forthcoming Journal of Labor Economics. 
Feinstein, J.S. M.K. Block and F.C. Nold (1985), 'Asymmetric information and collusive behavior in auction markets', American Economic Review, 75, June, pp. 441-460.

Gupta, S. (2001), 'The effect of bid rigging on prices: a study of the highway construction industry', Review of Industrial Organization, December, 19(4), pp. 453-467

Gupta, S. (2002), 'Competition and collusion in government procurement auction market', Atlantic Economic Journal, 30(1), March, pp. 13-25

Holtz-Eakin, D., Joulfaian, D., and H.S. Rosen (1994a), 'Entrepreneurial decisions and liquidity constraints', Journal of Political Economy, 102, pp. 53-75.

Holtz-Eakin, D., Joulfaian, D., and H.S. Rosen (1994b), 'Sticking it out: entrepreneurial survival and liquidity constraints', Rand Journal of Economics, Summer, 25(2), pp. 334-347.

Hout, M. and H.S. Rosen (2000), 'Self-employment, family background and race', Journal of Human Resources, 15(4), pp. 670-692.

Hurst, E. and A. Lusardi (2004), 'Liquidity Constraints, Household Wealth, and Entrepreneurship,' Journal of Political Economy, April, Vol. 112(2), pp. 319-347.

Ingraham, Allan, T. (2005), 'A test for collusion between a bidder and an auctioneer in sealed-bid auctions', Contributions to Economic Analysis \& Policy, Volume 4, Issue 1, pp. 1-32

Kessler, D.P. and L.F. Katz (2001), 'Prevailing Wage Laws and construction labor markets', Industrial and Labor Relations Review, 54(2), January, pp. 259-274.

Magri, S. (2008), ‘Household Wealth and Entrepreneurship’, Bank of Italy.

Marshall, R. (2000), 'Minority and female business development after Croson', University of Texas Working Paper.

Mora, M.T. and A. Da'vila (2006), 'Mexican immigrant self-employment along the U.S.-Mexico border: an analysis of 2000 Census data', Social Science Quarterly, 87(1), March.

Nykvist, J. (2008), 'Entrepreneurship and liquidity constraints: evidence from Sweden', Scandinavian Journal of Economics, forthcoming.

Olson, P.D., V. S. Zuiker and C.P. Montalto (2000), 'Self-employed Hispanics and Hispanic wage earners: differences in earnings', Hispanic Journal of Behavioral Sciences, 22, pp. 114-130.

Parker, S.C. (2002), 'Do banks ration credit to new enterprises and should governments intervene?', Scottish Journal of Political Economy, 49(2), May, pp. 162-195.

Porter, R. H. and D. J. Zona (1993), 'Detection of bid-rigging in procurement auctions,' Journal of Political Economy, 101(3), pp. 518-538. 
Quadrini, V. (2008), ‘Entrepreneurship in macroeconomics’, Annals of Finance, this issue.

Robles, B.J. and H. Cordero-Guzmán (2007), 'Latino self-employment and entrepreneurship in the United States: an overview of the literature and data sources', The Annals of the American Academy of Political and Social Science, 613; pp. 18-31.

Silver, M. (1986), Under construction: work and alienation in the building trades, Albany, State University of New York.

U.S. Chamber of Commerce (2005), Access to capital: what funding sources work for you?, U.S. Chamber of Commerce, May, Washington DC.

U.S. Department of Commerce (2006), Hispanic-owned firms: 2002, Washington, DC: 2002 Economics Census, Survey of Business Owners, Department of Commerce.

Wainwright, J. (2000), Racial discrimination and minority business enterprise: evidence from the 1990 Census, Studies in Entrepreneurship Series, New York and London: Garland Publishing.

Waldinger, R., and T. Bailey (1991), 'The continuing significance of race: racial conflict and racial discrimination in construction,' Politics and Society 19(3): 291-323.

Zuiker, V. S., M. J. Katras, C. P. Montalto, and P. D. Olson (2003), 'Hispanic self-employment: does gender matter?', Hispanic Journal of Behavioral Sciences, 25, pp.73-94. 
Appendix. Probability of being self-employed in the US private sector (dprobit)

Age
Age ${ }^{2}$
White female
Black
American Indian
Asian
Other races
Hispanic
Immigrant
$1^{\text {st }} 4^{\text {th }}$ grade
$5 / 6^{\text {th }}$ grade
$7 / 8^{\text {th }}$ grade
$9^{\text {th }}$ grade
$10^{\text {th }}$ grade
$11^{\text {th }}$ grade
$12^{\text {th }}$ grade no diploma
High school graduate
Some college no degree
Associate degree - occupational
Associate degree -- academic
BA
MA
MBA
PHD

State dummies

Industry dummies

$\mathrm{N}$

Pseudo $\mathrm{R}^{2}$
(1)

All industries

$.0107(35.26)$

$-.00007(22.52)$

$-.0357(22.22)$

-.0529 (21.18)

$-.0345(5.11)$

$-.0292(8.40)$

$-.0200(3.82)$

-.0424 (14.60)

.0051 (2.10)

$.0074(0.35)$

$.0043(0.23)$

.0800 (3.37)

.0589 (2.61)

.0795 (3.40)

.0599 (2.70)

.0703 (2.99)

.0747 (3.77)

.1061 (4.81)

.0918 (3.94)

.1047 (4.37)

.1479 (6.30)

.1749 (6.56)

.3927 (11.48)

.3203 (9.68)

50

46

166,519

.2005
(2)

Construction

.0272 (15.99)

$-.00022(11.44)$

$-.0913(8.14)$

$-.0743(4.41)$

$-.0556(1.70)$

$-.0428(1.51)$

$-.0114(0.40)$

$-.0925(6.62)$

$.0006(0.05)$

$.1221(1.32)$

.1068 (1.27)

$.2252(2.52)$

.1806 (2.06)

$.2402(2.68)$

.1844 (2.12)

.1711 (1.93)

.2058 (2.73)

$.2479(2.96)$

.2099 (2.41)

.2194 (2.47)

.3133 (3.57)

.2905 (3.11)

.1332 (1.03)

.1885 (1.07)

50

$\mathrm{n} / \mathrm{a}$

15,565

.0963

Source: Outgoing Rotation Group files of the Current Population Survey, 2007.

Notes: excluded categories: white males and $1^{\text {st }}$ grade. 